\title{
Application of Foreland Basin Detrital-Zircon Geochronology to the Reconstruction of the Southern and Central Appalachian Orogen
}

\author{
Hyunmee Park, David L. Barbeau Jr., Alan Rickenbaker, Denise Bachmann-Krug, \\ and George Gehrels ${ }^{1}$
}

Department of Earth and Ocean Sciences, University of South Carolina, Columbia, South Carolina 29208, U.S.A.

(e-mail: hpark@geol.sc.edu)

We report the U-Pb age distribution of detrital zircons collected from central and southern Appalachian foreland basin strata, which record changes of sediment provenance in response to the different phases of the Appalachian orogeny. Taconic clastic wedges have predominantly 1080-1180- and 1300-1500-Ma zircons, whereas Acadian clastic wedges contain abundant Paleozoic zircons and minor populations of 550-700- and 1900-2200-Ma zircons consistent with a Gondwanan affinity. Alleghanian clastic wedges contain large populations of 980-1080-Ma, 2700$\mathrm{Ma}$, and older Archean zircons and fewer Paleozoic zircons than occur in the Acadian clastic wedges. The abundance of Paleozoic detrital zircons in Acadian clastic wedges indicates that the Acadian hinterland consisted of recycled material and possible exposure of Taconic-aged plutons, which provided significant detritus to the Acadian foreland basin. The appearance of Pan-African/Brasiliano- and Eburnean/Trans-Amazonian-aged zircons in Acadian clastic wedges suggests a Devonian accretion of the Carolina terrane. In contrast, the relative decrease in abundance of Paleozoic detrital zircons coupled with an increase of Archean and Grenville zircons in Alleghanian clastic wedges indicates the development of an orogenic hinterland consisting of deformed passive margin strata and Grenville basement. The younging-upward age progression in Grenville province sources revealed in Taconic through Alleghanian successions suggest a reverse unroofing sequence that indicates at least two cycles of Grenville zircon recycling.
\end{abstract}

Online enhancements: appendix, data file.

\section{Introduction}

Sediments derived from orogenic hinterlands and adjacent quiescent cratons accumulate in foreland basins that develop in response to tectonic loading caused by subduction, continental collision, and/ or terrane accretion (Jordan 1995; DeCelles and Giles 1996). In the case of orogenic systems with sufficiently diverse sediment sources, spatial and temporal variations in foreland basin sediment provenance data can provide insight into the kinematics of deformation, landscape evolution, and sediment dispersal (Cawood and Nemchin 2001; McLennan et al. 2001). In recent years, U-Pb geochronology of individual detrital zircons has become one of the most useful approaches for identifying sediment sources in basins (Gaudette et al.

\footnotetext{
Manuscript received May 15, 2009; accepted August 4, 2009.

${ }^{1}$ Arizona LaserChron Center, Department of Geosciences, University of Arizona, Tucson, Arizona 85721.
}

1981; Gehrels et al. 1995; Fedo et al. 2003). Modern techniques of $\mathrm{U}-\mathrm{Pb}$ geochronology using laser ablation-multicollector-inductively coupled plasmamass spectrometry (LA-MC-ICP-MS) now allow rapid inexpensive determination of ages (Black et al. 2004; Gehrels et al. 2006). In this article, we use such data to address persistent questions relating to the tectonic development of the southern and central segments of the Paleozoic Appalachian orogen.

The Appalachian hinterland is partially composed of a complex mosaic of terranes that were amalgamated to the Laurentian margin during multiple phases of collision and related magmatism throughout Paleozoic time (fig. 1; Horton et al. 1989; Sinha et al. 1989; Hatcher 2005). Existing analyses of Appalachian detrital-zircon compositions indicate that sediments derived from hinter- 


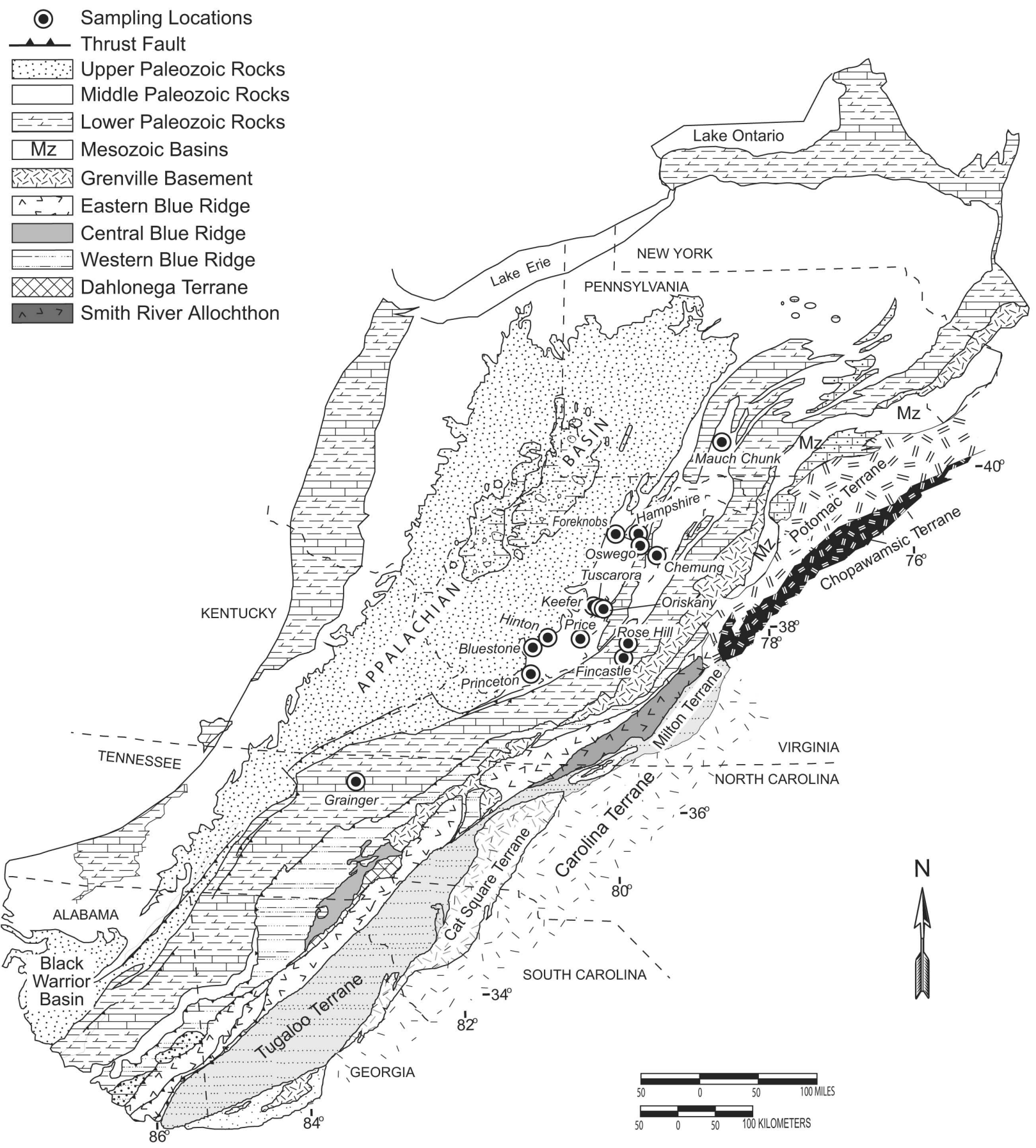

Figure 1. Simplified map of the Appalachian foreland basin and hinterland (modified from Millici and Witt 1988; Hatcher et al. 2004).

land accreted terranes are relatively minor in comparison to those originally derived from Grenville and related rocks that occur pervasively in the eastern Laurentian subsurface (Eriksson et al. 2004; Thomas et al. 2004; Becker et al. 2005). Despite the small sizes of these non-Grenville populations, such sediment should provide important data for the evaluation of Appalachian tectonic models, several of which remain poorly constrained or controversial. Here we report single-grain detrital-zircon $\mathrm{U}-\mathrm{Pb}$ and $\mathrm{Pb}-\mathrm{Pb}$ crystallization ages from 15 samples of Upper Ordovician to Mississippian 
sandstones collected along the central and southern Appalachians in Tennessee, West Virginia, Virginia, and Pennsylvania. The age distribution of detrital zircons from Pennsylvanian sandstones in the central and southern Appalachians are well established (e.g., Becker et al. 2005) and can be used to evaluate the provenance evolution of the Appalachian foreland basin together with our Ordovician to Mississippian samples. With these data, we examine the history of terrane accretion and kinematic evolution of the central and southern Appalachians.

\section{Geological Background}

The Appalachians are a 3,300-km-long orogen extending from Newfoundland to Alabama that formed through at least three Paleozoic orogenic events on the eastern margin of Laurentia (Williams 1978; Bradley 2008). Today the Appalachians consist of crystalline basement exhumed from the underlying Grenville province in addition to variably deformed and metamorphosed rift, passive margin, and foreland basin sedimentary rocks. These rocks record the development of the Laurentian passive margin caused by breakup of the supercontinent Rodinia and tectonic evolution associated with opening and closing of Atlantic-realm ocean basins (fig. 2). The breakup of Rodinia is recorded in two pulses of magmatic activity, including a failed rifting event at $\sim 700-760 \mathrm{Ma}$ and the opening of the Iapetus Ocean at $~ 550-620 \mathrm{Ma}$ (figs. 2, 3; Aleinikoff et al. 1995; Walsh and Aleinikoff 1999; Cawood et al. 2001). The first magmatic activity is preserved in the Mt. Rogers and Robertson River formations of the Blue Ridge and is characterized by bimodal igneous activity in an intracontinental rift system (fig. 3; Aleinikoff et al. 1995). Evidence of the younger 550-620-Ma rifting event is widespread in the northern Appalachians including the Pound Ridge Granite and the Catoctin Formation of the central and southern Appalachians (fig. 3; Aleinikoff et al. 1995; Rankin et al. 1997). Following the breakup of Rodinia, eastern Laurentia accumulated $3-5 \mathrm{~km}$ of passive margin sedimentary rocks represented by the Erwin, Hampton, and Unicoi formations of the Chilhowee Group, as well as the Shady Dolomite and the Rome and New Market formations in the central and southern Appalachians (fig. 2; Diecchio 1986; Fichter 1986; Read 1989).

This passive margin sedimentation was interrupted by the Taconic orogeny in the Middle Ordovician, presumably caused by progressive collision of an arc and continental fragments with the eastern Laurentian margin, resulting in the closure of the Iapetus Ocean (Drake et al. 1989). This collision produced the Taconic foreland basin that is well preserved in northern New York and involved uplift and carbonate deposition upon the forebulge and the accumulation of black shales and turbidites in the foredeep (Bradley 1989, 2008). In the hinterland, the orogeny involved significant magmatic activity, penetrative deformation, and granulitefacies and kyanite-grade metamorphism at $\sim 465$ Ma (Hatcher 1987; Drake et al. 1989; Bradley 2008). The accreted terranes responsible for this deformation and sediment accommodation presumably included 450-470-Ma magmatic arcs preserved in the Milton, Tugaloo, Potomac, and Chopawamsic terranes and $\sim 530$-Ma rocks of the Smith River Allochthon (fig. 1; Horton et al. 1989; Coler et al. 2000; Hibbard et al. 2003). In the study area, the synorogenic clastic wedges associated with this Taconic deformation are represented by the Martinsburg Formation, the Oswego Sandstone, and the Juniata Formation (fig. 2).

Silurian to Early Devonian time in the Appalachians was a period of orogenic quiescence between the Taconic and Acadian orogenies (Johnson et al. 1985; Ettensohn 1991). During this time, Upper Silurian to Lower Devonian strata accumulated in the Appalachian foreland basin and are characterized by eustatically controlled sequences including the Tuscarora Sandstone, the Rose Hill Formation, and Keefer Sandstone of the Clinton Group; the McKenzie Formation; the Helderberg Group; and the Oriskany Sandstone in West Virginia and Virginia (fig. 2; Johnson et al. 1985; Brett et al. 1990).

The Devonian to Early Mississippian Acadian orogeny is generally regarded as the result of the collision of the Avalonian microcontinent to the margin of eastern Laurentia in the northern Appalachians, and the accretion of the Carolina terrane in the southern and central Appalachians (Osberg et al. 1989; Wortman et al. 2000). These collisions are also recorded by $\sim 384-423-\mathrm{Ma}$ plutonism and the cratonward migration of northern Appalachian deformation front (Bradley et al. 2000). In comparison to widespread evidence of the Acadian orogeny in the northern Appalachians, the Acadian orogeny is poorly manifested in the southern and central Appalachian hinterland outside of 374-382-Ma granitoid plutonism in the eastern Blue Ridge and late Acadian metamorphism in the Cat Square terrane (Horton et al. 1989; Osberg et al. 1989; Hatcher 2005). Acadian synorogenic deposits are known broadly as the Catskill clastic wedge and are present from New England to Georgia (Faill 1985; Osberg et al. 1989). In West Virginia, these rocks are represented by the Devonian-Lower 


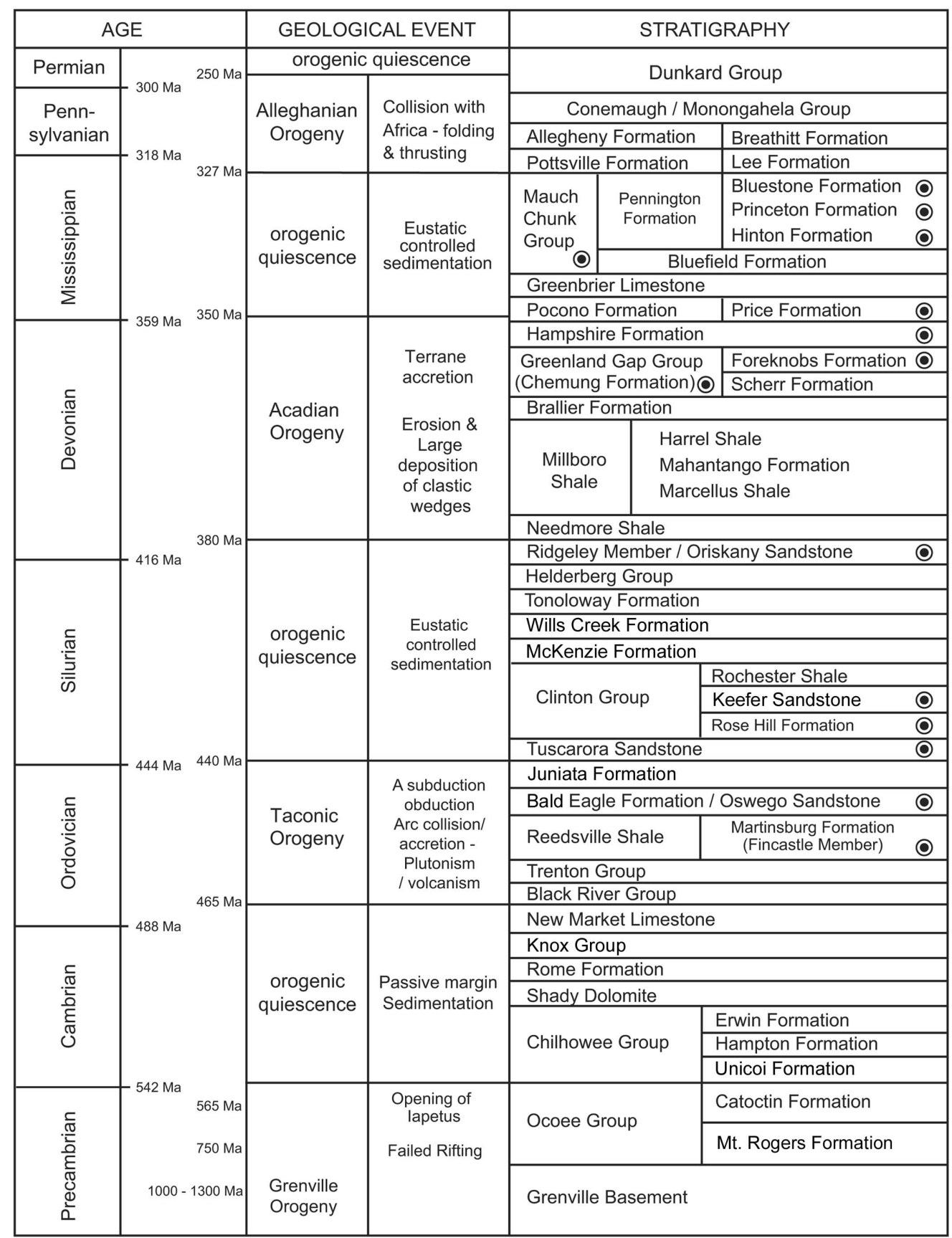

Figure 2. Stratigraphic column depicting the geologic history of the southern and central Appalachians (Johnson et al. 1985; Diecchio 1986; Fichter 1986; Hatcher 1987, 2005; Johnson 1987; Ettensohn 1994; Aleinikoff et al. 1995; Eriksson et al. 2004). On the right, sampled stratigraphic units are shown with circled dots.

Mississippian Chattanooga-Brallier, Chemung, Foreknobs, Hampshire, and Pocono formations (fig. 2). Following the Acadian orogeny, interorogenic deposition preceding the Alleghanian orogeny is recorded by the Mississippian Greenbrier Limestone in West Virginia (Wynn et al. 2006).
The culminating orogenic event of the Appalachians is the Late Mississippian-Pennsylvanian Alleghanian orogeny that involved an oblique, transpressive, and rotational collision between part of Gondwana and previously accreted peri-Gondwanan assemblages, causing the formation of the 


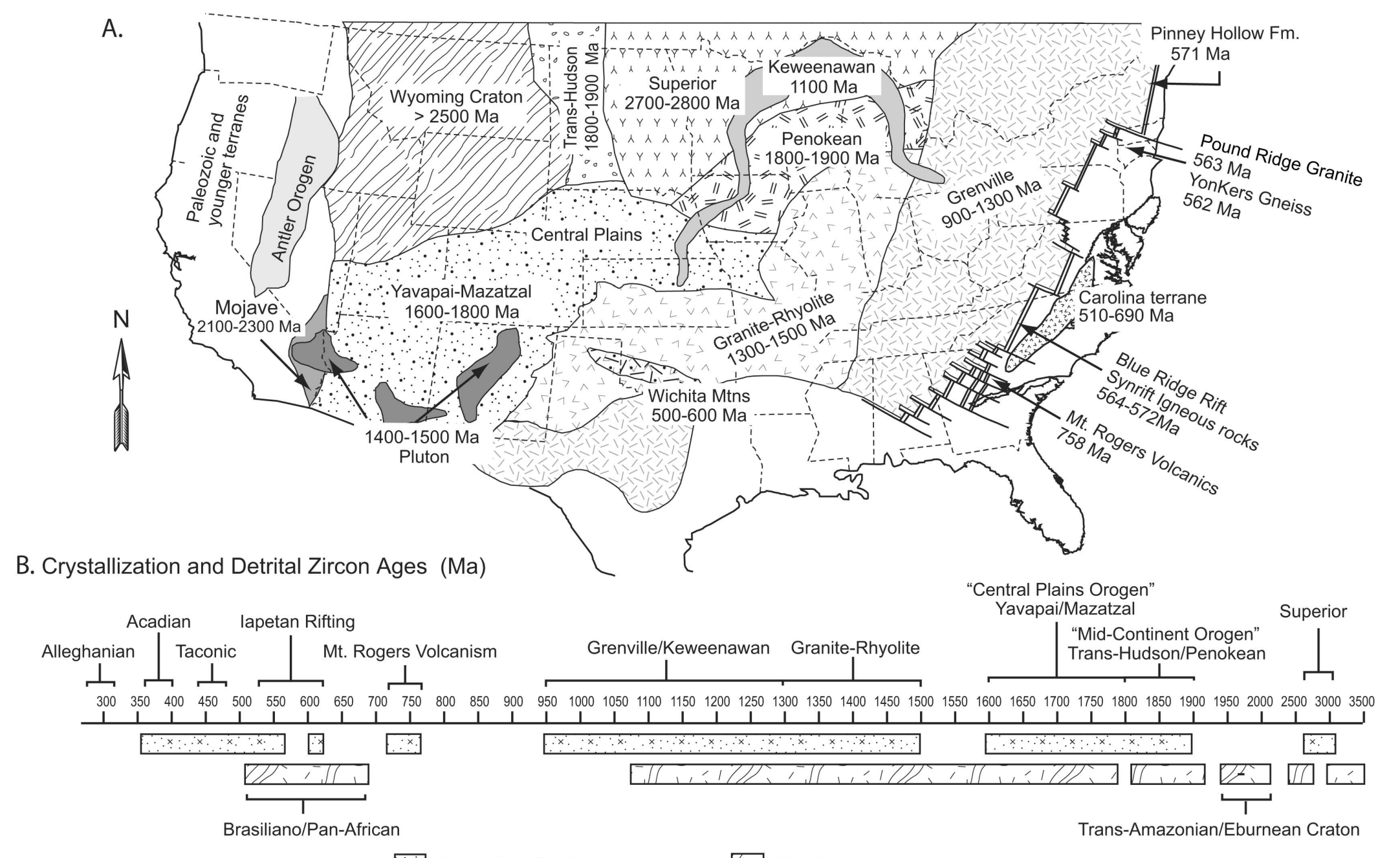

Figure 3. A, Laurentian basement provinces and magmatism ages in central North America including cratonic and Grenville provinces (modified from Hoffman 1989; Van Schmus et al. 1993), and the late Precambrian-early Cambrian rift margin (Thomas 1991; Williams et al. 1995; Rankin et al. 1997; Walsh and Aleinikoff 1999; Cawood et al. 2001; Thomas et al. 2004; Bradley 2008). B, Laurentian and Gondwanan tectonic events (Becker et al. 2005): peri-Gondwanan ages are from Mueller et al. (1994), Ingle-Jenkins et al. (1998), Coler and Samson (2000), Wortman et al. (2000), and Samson et al. (2001). Laurentian ages are from Hoffman (1989), Van Schmus et al. (1993), and Aleinikoff et al. (1995). 
Pangean supercontinent (Hatcher et al. 1989). In the central and southern Appalachians, the Alleghanian orogeny involved: (1) accretion of the Archean Suwannee terrane to the southeast margin of Laurentia (fig. 1; Horton et al. 1989; Heatherington et al. 1999), (2) lateral translation of previously accreted terranes along dextral strike-slip faults (Hatcher and Bream 2002; Dennis 2007), (3) 300325-Ma subduction-related magmatism and greenschist to amphibolite facies regional metamorphism of hinterland terranes (Hatcher et al. 1989; Hatcher 2005), and (4) development of a foreland fold-thrust belt that propagated into sedimentary rocks from the allochthonous pre-Alleghanian metamorphic rocks in the southern and central Appalachians (Hatcher et al. 1989). The orogeny exposed Grenville basement and earlier orogenic foreland basin strata producing the Blue RidgePiedmont thrust sheets (Hatcher et al. 1989, 2004). The lower Alleghanian clastic wedges examined herein record an up-section transition from marine limestone (Greenbrier Formation) to marine or brackish-water clastic deposition (Mauch Chunk Group and younger strata) in the central and southern Appalachians (fig. 2).

\section{Geochronologic Provinces}

The ages of detrital zircons in Appalachian foreland basin strata are generally divisible into those of Laurentian and Gondwanan affinities, although those associated with the Grenville orogen are also known on several Laurentian and Gondwanan fragments (Becker et al. 2005). Evaluation of the origin of detrital zircons in the basin is not always easy to interpret because some Laurentian crustal ages and/or geological events overlap with those of Gondwanan affinity. For example, the opening of the Iapetus Ocean adjacent to Laurentia occurred during the Pan-African/Brasiliano orogenies in Gondwana (fig. 3). Moreover, sediment recycling known in the Appalachian basin (McLennan et al. 2001) is likely to have mixed Laurentian and Gondwanan components, complicating the interpretation of sediment provenance. These challenges in identifying the Gondwanan versus Laurentian components can be overcome by assembling detrital zircon ages representative of a certain continent and examining presence and/or absence of unique components (Samson et al. 2001; Fedo et al. 2003; Bream et al. 2004). Below we review the pre-Appalachian orogenic events that occurred in Laurentian and Gondwanan provinces that could pertain to the zircon ages recovered from the Appalachian foreland basin.

Laurentian Craton Interior Provinces. Potential source provinces of Laurentian affinity for the Appalachian foreland basin include the Superior, Wyoming, Trans-Hudson, Penokean, Yavapai, Mazatzal, and Granite-Rhyolite provinces and orogens (fig. 3A). The Archean Superior province comprises the Laurentian shield and largely constitutes amalgamated island arcs formed at $\sim 2700-2800 \mathrm{Ma}$, with small regions of pre-3500-Ma crust (Hoffman 1989). The Wyoming province consists mainly of 2500-2700-Ma granites and gneisses, and includes $\sim 1600-1800-\mathrm{Ma}$ accreted terranes and $>3500-\mathrm{Ma}$ continental crust composed of metamorphosed shelf-type sedimentary rocks (Wooden and Mueller 1988). The Trans-Hudson province is a collisional zone between the Superior province and the $\mathrm{Wy}$ oming province and consists mainly of $\sim 1800$ 1900-Ma metasedimentary rocks (Hoffman 1989). The Penokean province is a Paleoproterozoic accretionary orogen along the southern margin of the Superior province and is composed of $\sim 1800-1900$ Ma magmatic terranes (Van Schmus et al. 1993; Sims 1996). In southwestern Laurentia, the Yavapai province is defined by deformed volcanic arc terranes accreted to North America by 1700-Ma and includes a basement of juvenile felsic igneous rocks formed at 1700-1760 Ma (Van Schmus et al. 1993; Holm et al. 2007). The Mazatzal province is an assemblage of $\sim 1700-1800-\mathrm{Ma}$ accretionary prism blocks accreted to the southern Yavapai province during the 1600-1660-Ma Mazatzal orogeny (Bennett and DePaolo 1987; Karlstrom and Bowring 1988; Amato et al. 2008). The Yavapai and Mazatzal provinces are adjoined in the southeast to the Granite and Rhyolite province that consists of $\sim 1360$ 1500-Ma crust formed as the result of high-silica magmatism (Nyman et al. 1994). On the basis of ages, position and/or internal arrangement of the provinces, we include the Yavapai and Mazatzal provinces within the "Central Plains orogens" and refer to the Trans-Hudson and Penokean provinces as the "midcontinent orogens" (fig. 3B).

Grenville Province. The Grenville orogen was produced by final amalgamation of the supercontinent Rodinia resulting from numerous continentcontinent collisions during the interval $~ 900-1300$ $\mathrm{Ma}$, and it occurs on numerous modern continents, including the north-central Andean regions of South America, northern Mexico, Central America, southwest Australia, east Antarctica, east-central India, west Africa, Scandinavia, and eastern North America (Moores 1991; Keppie and Ortega-Gutier- 
rez 1999|. In modern North America, the Grenvilleage province comprises the eastern margin of Laurentia extending from Newfoundland to Texas and central Mexico (fig. 3; Mezger et al. 1993). Based on magmatic and deformational events near the Adirondack Mountains in the northern Appalachians, the Grenville event has been subdivided into phases associated with arc-related and accretionary events during the 1220-1350-Ma Elzevirian orogeny and the subsequent Shawinigan orogeny (ca.1160-1190 Ma) and a continent-continent collision during the $\sim 980-1090-M a$ Ottawan orogeny (Rivers 1997; Heumann et al. 2006). Widespread magmatism resulting from lithospheric delamination associated with orogenic collapse is recorded at $\sim 1145-1160 \mathrm{Ma}$, which overlapped with the early Shawinigan events (McLelland et al. 2004). Subsurface analysis has revealed that the Grenville rocks underlie much of the central and southern Appalachian foreland basin and also occur as several basement massifs in the southern Blue Ridge of the Appalachian mountain belt (Williams and Hatcher 1983; Hatcher et al. 2004). As has been demonstrated by previous detrital-zircon studies, the Grenville province provided a primary sediment source for the Appalachian foreland basin (Gray and Zeitler 1997; McLennan et al. 2001; Eriksson et al. 2004; Thomas et al. 2004; Becker et al. 2005).

Rift Successions and Appalachian Magmatic Rocks. Several late Proterozoic crustal fragments formed along the eastern margin of Laurentia during the Rodinian rifting event that began $\sim 800 \mathrm{Ma}$ and ended $550 \mathrm{Ma}$ (Aleinikoff et al. 1995; Hoffman 1999). Rodinia rifted apart $\sim 750 \mathrm{Ma}$ in western and northeastern North America but failed to rift in the central and southern Appalachians (fig. 3). The failed rifting is recorded in the Grandfather Mountain, Robertson River, and Mount Rogers formations, which consist of marine, nonmarine, and 732-758-Ma bimodal volcanic rocks in North Carolina, Tennessee, and Virginia (Lukert and Bank 1984; Aleinikoff et al. 1995; Hatcher 2005). Successful rifting of Rodinia in the southern and central Appalachians occurred at $~ 550-600 \mathrm{Ma}$ and is represented by siliciclastic sedimentary rocks of the Swift Run and Lynchburg Groups, the Yonkers Gneiss, the Pound Ridge Granite (fig. 2; Wehr and Glover 1985; Rankin et al. 1997) and volcanic and sedimentary rocks of the Catoctin Formation (Badger and Sinha 1988; Aleinikoff et al. 1995; Eriksson et al. 2004). The rift-related rocks are widely considered to have provided significant amounts of detritus to the foreland basin during the Appala- chian orogenies (Thomas et al. 2004). Synorogenic igneous rocks ( 350-490 Ma) crystallized during the Taconic and Acadian orogenies also became an important source for the Acadian and Alleghanian clastic wedges (McLennan et al. 2001; Thomas et al. 2004; Becker et al. 2005).

Gondwanan Components. Gondwana was a composite supercontinent consisting of six major cratons whose amalgamation was triggered by closure of Neoproterozoic oceans during the Pan-African orogeny in Africa and the Brasiliano orogeny in South America (Hoffman 1999). These orogenies began at $\sim 820 \mathrm{Ma}$ by the joining of the Congo and Kalahari cratons, which accreted to greater India at $\sim 680 \mathrm{Ma}$ and West Africa at $610 \mathrm{Ma}$ and was completed by $\sim 550 \mathrm{Ma}$ through the accretion of the Australia-Antarctica and Amazonia cratons (Hanson et al. 1994; Hoffman 1999). These amalgamation events involved the generation of new crustal material, including zircon-bearing felsic and intermediate units.

Plate reconstructions indicate that the Rondonian-San Ignacio province in Gondwana's western Amazonian craton was adjacent to modern Ontario and New York (e.g., Hoffman 1991) as part of the Rodinian supercontinent. These rocks are composed of 1300-1550-Ma metamorphic belts, accretionary domains, and plutonic bodies (Geraldes et al. 2001; Teixeira et al. 2009) and may have transferred material to Laurentia during Rodinian times.

In addition to these Neoproterozoic and Mesoproterozoic ages, western Gondwana cratons preserved the $\sim 1800-2250-\mathrm{Ma}$ crustal-forming event known as the Trans-Amazonian orogeny in South America and the 2050-2150-Ma tectonothermal event known as the Eburnean orogeny in the West African craton and the western Congo (Hartmann 2002; Schofield et al. 2006; Schofield and Gillespie 2007; Santos et al. 2008). The Trans-Amazonian orogen is represented by a series of juvenile magmatic arcs, anorogenic magmatic belts, and large rifts and disruptive structures associated with the development of cratonic volcano-sedimentary basins (Hartmann 2002). In contrast, the Eburnean orogen is represented by supracrustal basaltic and granitic rocks and underwent sinistral transpressional deformation (Schofield et al. 2006).

The ages of 1900-2250-Ma Trans-Amazonian/ Eburnean and 530-680-Ma Pan-African/Brasiliano events are generally distinct from the Laurentian crustal ages and thus distinguish the terranes associated with Gondwana (e.g., the Suwannee, Carolina, and Avalon terranes) that were accreted to Laurentia during the Appalachian orogenies 
(Heatherington et al. 1999; Wortman et al. 2000; Hibbard et al. 2002).

\section{Sample Preparation and Analysis}

Samples analyzed for this study along with brief stratigraphic descriptions and GPS coordinates for each sample location are listed in appendix table A1, available in the online edition or from the Journal of Geology office. The separation of detrital zircons from sampled sandstones was performed in the Tectonics and Sedimentation Laboratory at the University of South Carolina, mainly following the methods of Gehrels et al. (2006) but with minor modifications. In order to disaggregate sand-sized grains, approximately 5-10 kg of each sandstone sample was crushed using a Bico WD Chipmunk Jaw crusher, a Bico UD pulverizer, and an 18-mesh sieve. Heavy minerals were separated and concentrated with a MD Mineral Technologies MK 2 Gemeni table and hand-operated ABS plastic gold pan. An S. G. Frantz L1 magnetic separator was used to remove remaining magnetic heavy minerals. The Frantz magnetic separator was operated stepwise via 0.25 -A increments from 0.25 to $1.75 \mathrm{~A}$, with horizontal and vertical angles set to $15^{\circ}$ and $25^{\circ}$, respectively. The samples were separated by density through the heavy liquids sodium polytungstate (density $2.89 \mathrm{~g} / \mathrm{cm}^{3}$ ), a lithium heteropolytungstate solution (density $2.90 \mathrm{~g} / \mathrm{cm}^{3}$ ), and/or methylene iodide (density $3.30 \mathrm{~g} / \mathrm{cm}^{3}$ ) in $125-\mathrm{mL}$ Pyrex separatory funnels and/or 10-mL centrifuge tubes.

The prepared samples were analyzed by LA-MCICP-MS in the Arizona LaserChron Center at the University of Arizona. One hundred zircons were randomly selected from each sample for ablation with a DUV193 ArF Exciplex laser using a $35-\mu \mathrm{m}$ spot for 14 samples and a $25-\mu \mathrm{m}$ spot for the Foreknobs Formation sample because of its finergrained zircons. Laser spot selection targeted areas that were sufficiently clean and large to accept the laser spot, which favors zircon cores. Because our postacquisition processing excludes grains with large spatial variations in age data, which would result from the mixing of rim and core compositions, we did not perform cathodoluminescence imaging of grains before ablation, in line with other recent laser-ablation detrital-zircon geochronology studies that prioritize the rapid generation of large data sets at the expense of detailed grain characterization. All isotopic measurements were made in static mode, using Faraday detectors for ${ }^{238} \mathrm{U}$, ${ }^{232} \mathrm{Th},{ }^{208} \mathrm{~Pb},{ }^{207} \mathrm{~Pb}$ and ${ }^{206} \mathrm{~Pb}$ and an ion-counting Channeltron for ${ }^{204} \mathrm{~Pb}$. Data were collected through reference to a large zircon standard (SL: $564 \pm 4$ $\mathrm{Ma}, 2 \sigma)$, which was analyzed after every fifth unknown. Interpreted ages older than $800 \mathrm{Ma}$, which compose a natural break for the Appalachian crystallization ages, were calculated from ${ }^{206} \mathrm{~Pb} /{ }^{207} \mathrm{~Pb}$, whereas ages younger than $800 \mathrm{Ma}$ were based on ${ }^{206} \mathrm{~Pb} /{ }^{238} \mathrm{U}$. Common $\mathrm{Pb}$ correction was achieved by the measured ${ }^{204} \mathrm{~Pb}$ in conjunction with an initial $\mathrm{Pb}$ composition from Stacey and Kramers (1975) with uncertainties of 1.0 for ${ }^{206} \mathrm{~Pb} /{ }^{204} \mathrm{~Pb}$ and 0.3 for ${ }^{207} \mathrm{~Pb} /{ }^{204} \mathrm{~Pb}$. For each analysis, the $2 \sigma$ error was used to determine whether the scatter in a given group was consistent with the internal errors, but we present data in our tables and figures at the $1 \sigma$ level. We employed only grains that were $<30 \%$ discordant or $<5 \%$ reverse discordant for provenance analyses. Further details are provided in an Excel data file with $\mathrm{U}-\mathrm{Pb}$ data, available in the online edition or from the Journal of Geology office. Graphical representation of our data using concordia and probability plots used standard routines offered by IsoPlot (Ludwig 2003).

\section{Results}

The results from 15 individual detrital zircon samples are plotted on concordia diagrams (fig. 4) and age-probability plots (fig. 5). Maximum depositional ages determined from our detrital-zircon analysis are shown in table 1 along with independently constrained depositional ages for each sample.In general, the major age populations of detrital zircons from the Appalachian foreland basin strata are $900-1300 \mathrm{Ma}$, correlative with the Grenville province. The age range of $\sim 1300-1500 \mathrm{Ma}$ is correlative with the Granite-Rhyolite province, the later stages of Grenville magmatism and metamorphism, and, potentially, terranes derived from the Trans-Amazonian craton (fig. 2B). Although these zircon ages do not distinguish these sources, we consider that the Granite-Rhyolite province is primary source for the central and southern Appalachian foreland basin based on the size of province and distance to the depositional site (see "Discussion"). Considerable 440-480-Ma detrital zircons, which are coeval with Taconic magmatism and metamorphism (Gray and Zeitler 1997; McLennan et al. 2001), appear in Acadian through Alleghanian samples (fig. 5). There were minor age populations at $\sim 1600-1900 \mathrm{Ma}$ and $\sim 2700 \mathrm{Ma}$, ages similar to those of the midcontinent and Central Plains orogens and the Superior province in the Laurentian interior provinces, respectively, as well as to the ages of terranes that originated in the Trans-Amazonian and/or Ebumean cratons. An q11

q12 


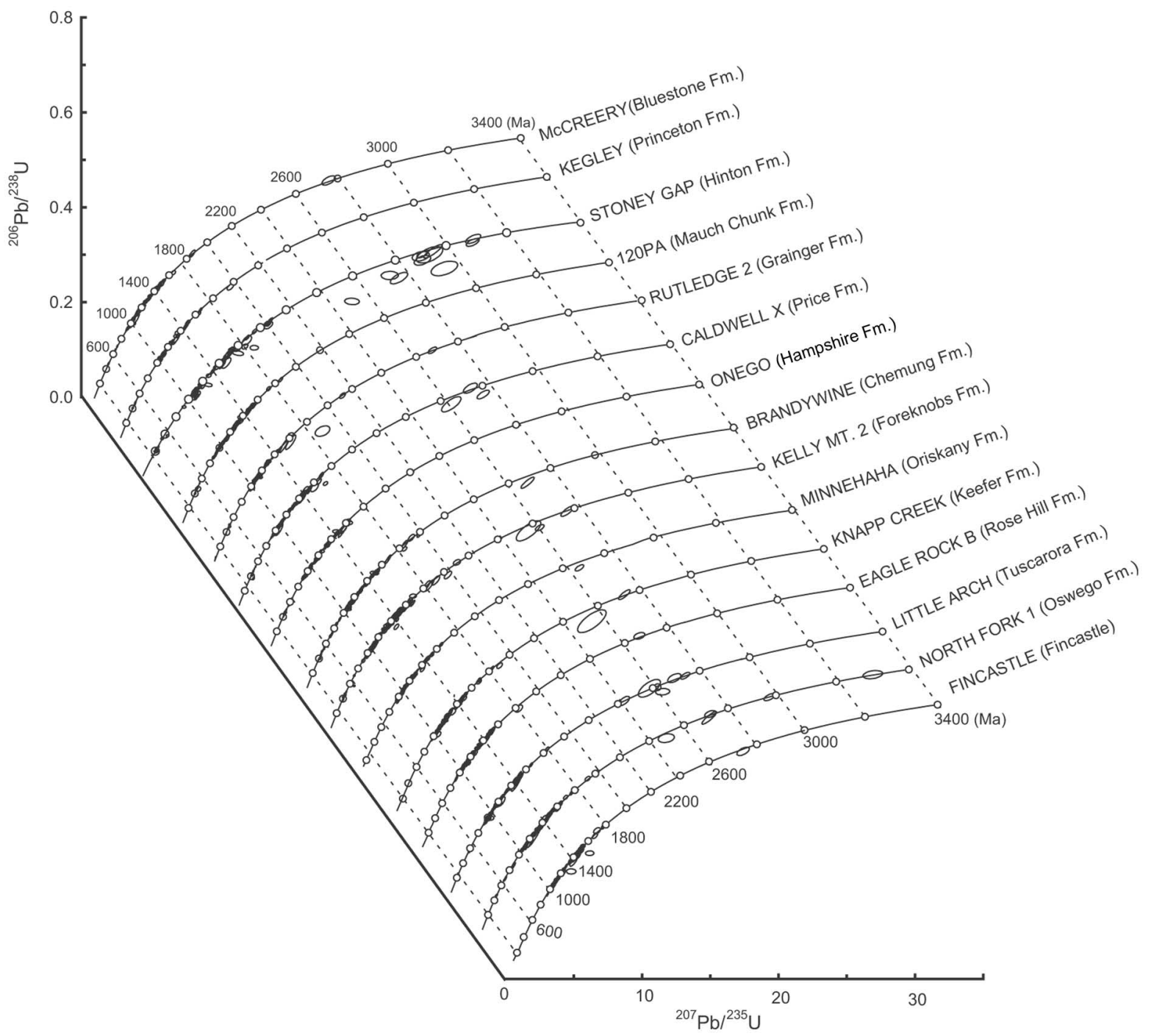

Figure 4. Concordia plots of ${ }^{206} \mathrm{~Pb} /{ }^{238} \mathrm{~Pb}$ versus ${ }^{207} \mathrm{U} /{ }^{235} \mathrm{~Pb}$ * and corresponding ages (in 200-m.yr. increments) for zircons analyzed in this study. Data-point error ellipses are at the $68.3 \%$ confidence level.

abrupt change in zircon age distribution recognized by an abundance of Paleozoic zircons is observed at the transition between the Foreknobs and Oriskany formations (fig. 5). In the Acadian and Alleghanian clastic wedges, detrital zircon age populations vary but tend to have a significant young component that is largely absent from other strata. In the Silurian sandstones, zircon populations are largely restricted to those of Grenville age. In addition to single sample probability curves, we plot samples with similar tectonic significance together in order to characterize the age distribution of detrital zircons in different tectonic phases of the Appalachian orogeny (fig. 6), which we describe below.

Taconic Clastic Wedges. Samples collected from
Upper Ordovician Taconic foreland basin units $(N=2, n=185)$ contain prominent populations consistent with ages of the Grenville and GraniteRhyolite provinces. Approximately $52 \%$ of zircons have Grenville ages, and $29 \%$ fall within the age range of the Granite-Rhyolite province (fig. 6).

The Grenville-age population consists of two distinct peaks that occur at $\sim 1088$ and $1176 \mathrm{Ma}$ and that are also observed in our Silurian, Acadian, and Alleghanian samples. The basement of the northern Blue Ridge consists of different age groups of Proterozoic granitic gneisses, including $\sim 1140$ 1190-Ma and $1020-1090$-Ma groups, which have been respectively correlated with the Shawinigan and Ottawan phases of the Grenville orogeny de- 


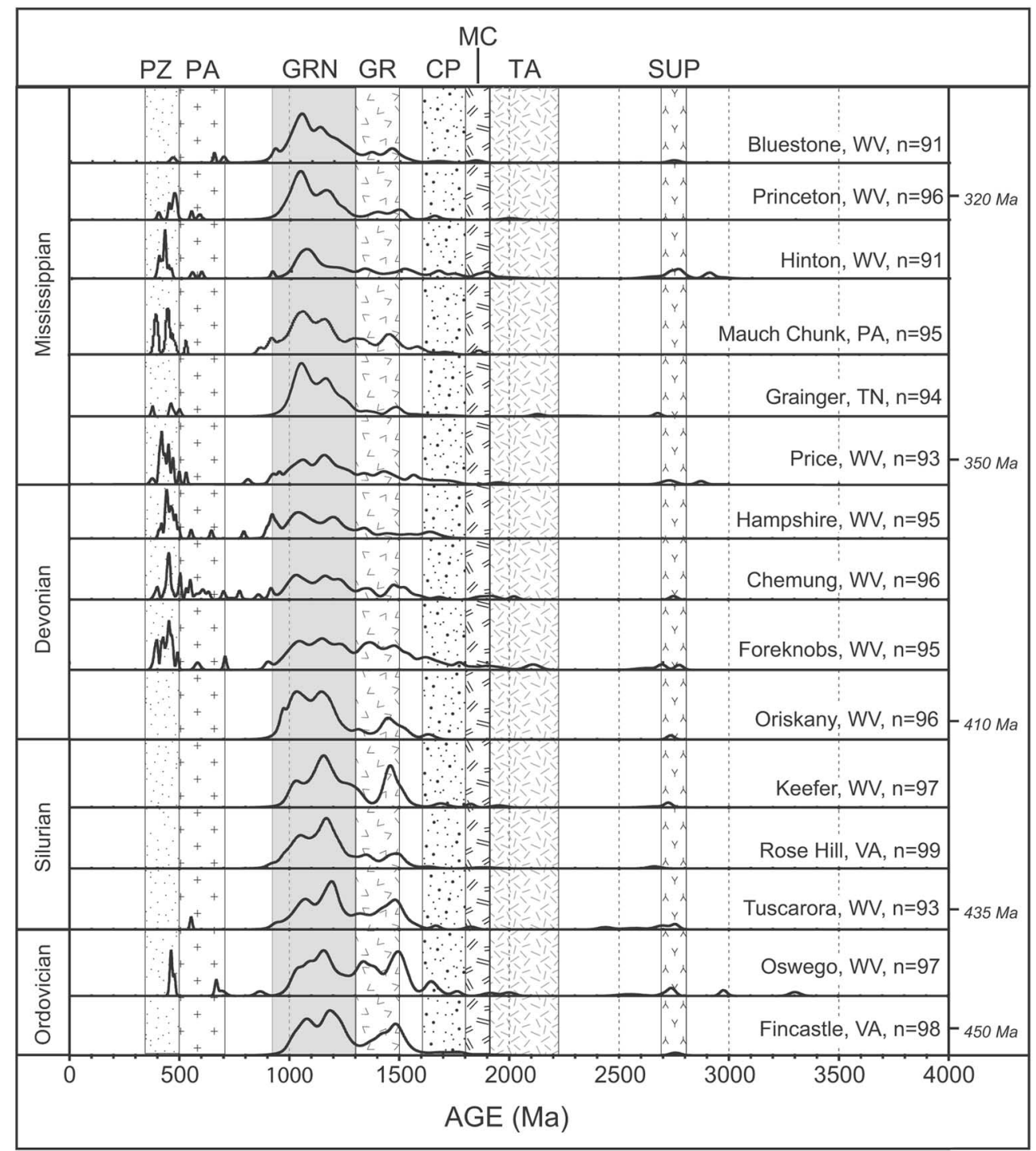

Figure 5. Detrital-zircon probability plots from the upper Ordovician to Mississippian sandstones of the Appalachian basin. $P Z=$ Paleozoic crust, $P A=$ Pan-African/Brasiliano crust, $G R N=$ Grenville province, $G R=$ granite-rhyolite province, $M C=$ midcontinent orogen, $C P$ : Central-Plains orogen, $T A=$ trans-Amazonian crust, $S U P=S u p e r i o r$ province.

fined in the Adirondacks and Canada (Aleinikoff et al. 2000). The peak ages at $1088 \mathrm{Ma}$ and $1176 \mathrm{Ma}$ in our Taconic samples coincide with the Ottawan and the Shawinigan orogenies, respectively. The Taconic samples also contain minor peaks at 1652 and $1776 \mathrm{Ma}$, which correspond with Central Plains orogen ages, and at 2985 and $3320 \mathrm{Ma}$, which correspond to the Archean Laurentian provinces, including the Superior province.

Post-Taconic Strata Deposited during Orogenic Quiescence. The Tuscarora, Rose Hill, Keefer and Oriskany formations were deposited during the Si- lurian to early Devonian orogenic quiescence (Fichter 1986; Ettensohn 1994; Castle 2001). Approximately $87 \%$ of the analyzed zircons from these samples $(N=4, n=385)$ cluster at ages consistent with the Grenville and Granite-Rhyolite provinces (fig. 6). Among the Grenville-age zircons, the Shawinigan-phase (peak at $1173 \mathrm{Ma}$ ) zircons are more abundant than Ottawan-phase (peak at 1063 Ma) zircons (fig. 6). The remaining $13 \%$ of the zircons are older, with U-Pb ages of $\sim 1600-1900$ and $\sim 2700 \mathrm{Ma}$ that are associated with the midcontinent orogen and Superior province, respectively. 
Table 1. Depositional Ages

\begin{tabular}{|c|c|c|c|c|}
\hline \multirow[b]{2}{*}{ Period, stratigraphic unit } & \multirow[t]{2}{*}{$\begin{array}{l}\text { Maximum } \\
\text { depositional } \\
\text { age (youn- } \\
\text { gest age; } \\
\text { Ma) from } \\
\text { U-Pb } \\
\text { analysis }\end{array}$} & \multicolumn{2}{|c|}{ Depositional ages } & \multirow[b]{2}{*}{ References } \\
\hline & & Epoch/stage & Ma (approximate) & \\
\hline \multicolumn{5}{|l|}{ Mississippian: } \\
\hline Bluestone Formation & $658(471)$ & Late Chesterian & $316-319$ & $\begin{array}{l}\text { Jones 1996; Davydov et al. 2004; Maynard } \\
\text { et al. } 2006 \\
\text { Jones 1996; Davydov et al. 2004; Maynard }\end{array}$ \\
\hline Princeton Formation & $454(406)$ & Late Chesterian & 320 & $\begin{array}{l}\text { et al. 2006 } \\
\text { Jones 1996; Davydov et al. 2004; Maynard }\end{array}$ \\
\hline $\begin{array}{l}\text { Hinton Formation } \\
\text { Mauch Chunk Formation }\end{array}$ & $392(392)$ & Middle Chesterian & $320-324$ & et al. 2006 \\
\hline (Undivided) & $393(393)$ & Middle Chesterian & $320-339$ & $\begin{array}{l}\text { Cardwell et al. } 1968 \\
\text { Cardwell et al. } 1968 ; \text { Matchen and Kam- }\end{array}$ \\
\hline Grainger Formation & $456(376)$ & Kinderhookian & $349-359$ & mer 1994 \\
\hline Price Formation & $405(375)$ & Kinderhookian & $349-359$ & Matchen and Kammer 1994 \\
\hline \multicolumn{5}{|l|}{ Devonian: } \\
\hline Hampshire Formation & $407(407)$ & Famennian & $359-374$ & $\begin{array}{l}\text { Berg et al. 1983; Millici and Witt 1988; } \\
\text { Castle } 1998\end{array}$ \\
\hline Chemung Formation & $390(390)$ & Frasnian, earliest Famennian & $375-385$ & Millici and Witt 1988; Hughes 2001 \\
\hline Foreknobs Formation & $385(385)$ & Frasnian, earliest Famennian & $375-385$ & Hughes 2001 \\
\hline Oriskany Formation & $963(963)$ & Pragian & $407-411$ & Tucker et al. 1998; Ver Straeten 2004 \\
\hline \multicolumn{5}{|l|}{ Silurian: } \\
\hline Keefer Formation & $1002(967)$ & Late Llandovery & 428 & Cardwell et al. 1968 \\
\hline Rose Hill Formation & $972(921)$ & Middle Llandovery & 430 & Cardwell et al. 1968 \\
\hline Tuscarora Sandstone & $939(553)$ & Early Llandovery & 435 & Cardwell et al. 1968; Diecchio 1986 \\
\hline \multicolumn{5}{|l|}{ Ordovician: } \\
\hline Oswego Formation & $461(461)$ & Gamachian-late Richmondian & 443 & Knowles 1966; Robert et al. 1992 \\
\hline $\begin{array}{l}\text { Fincastle Member, Martinsburg } \\
\text { Formation }\end{array}$ & & Latest Maysvillian through ear- & & \\
\hline Formation & $1011(1011)$ & liest Richmondian & 450 & Walker 1978; Wise et al. 2007 \\
\hline
\end{tabular}

Note. Maximum depositional ages are from $\mathrm{U}-\mathrm{Pb}$ analysis. 


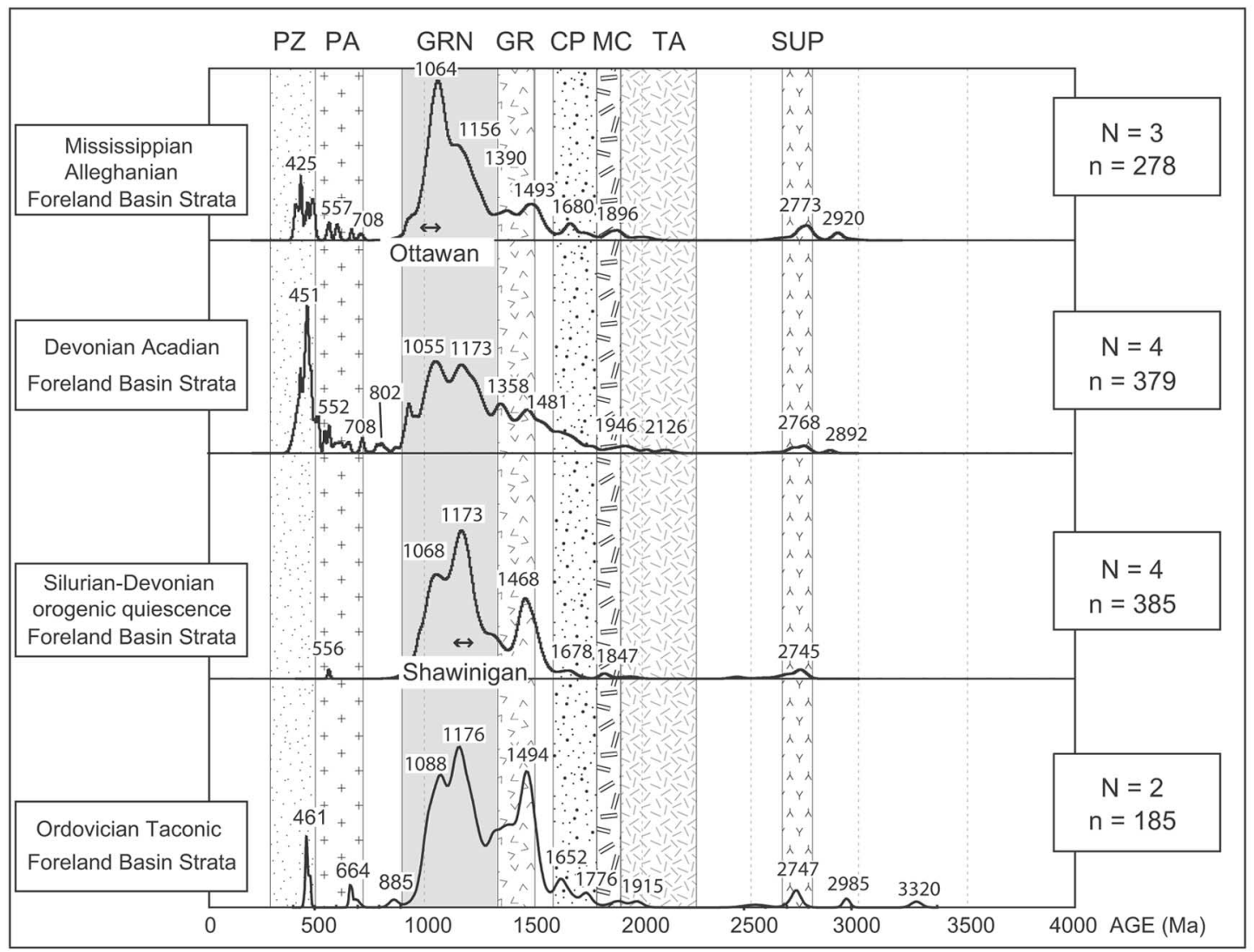

Figure 6. Detrital-zircon probability plots for Taconic, interorogenic, Acadian, and Alleghanian foreland strata from West Virginia and Virginia. Arrows represent different orogenic events in the Grenville Province: Shawinigan orogeny, 1140-1190 Ma; Ottawan orogeny, 1020-1090 Ma. Same abbreviations as in figure 5.

The Silurian to Devonian samples do not contain zircons younger than $800 \mathrm{Ma}$, suggesting no contributions from Paleozoic Appalachian magmatic rocks or from the Pan-African orogen.

Acadian Clastic Wedges. Samples collected from Devonian synorogenic clastic wedges of the central Appalachian foreland basin $(N=4, n=379)$ contain a more varied distribution of ages, contrasting with the Silurian formations deposited during preAcadian tectonic quiescence (fig. 6). Approximately $79 \%$ of the zircons in Acadian foreland basin strata were derived from Laurentian sources, primarily from the Grenville and Granite-Rhyolite provinces $(67 \%)$, the midcontinent and Central Plains orogens $(9 \%)$, and the Superior and other provinces $(3 \%)$. Remarkable aspects of detrital-zircon ages in the Acadian strata include $(a)$ the occurrence of a significant amount of young $(<500-\mathrm{Ma})$ zircons consistent with ages of magmatism associated with the Taconic $(11 \%)$ and Acadian $(3 \%)$ orogenies and $(b)$ the occurrence of zircons similar to the 500-700-
Ma Pan-African (4\%) and 1900-2250-Ma TransAmazonian/Eburnean (2\%) events, which are considered to have Gondwanan affinities (Excel data file). Moreover, zircons derived from Shawinigan and the Granite-Rhyolite provinces are considerably less abundant in the Acadian strata compared to older strata (fig. 6).

Alleghanian Clastic Wedges. Samples collected from Mississippian foreland basin units $(N=3$, $n=278$ ) contain $30 \%$ zircons associated with the Ottawan orogeny (peak at $1064 \mathrm{Ma}$ ), and relatively few zircons coeval with the Shawinigan (peak at $1156 \mathrm{Ma}$ ) orogeny and Granite-Rhyolite province (minor peaks at 1393 and $1493 \mathrm{Ma}$ ), representing $18 \%$ and $14 \%$ of the total population, respectively (fig. 6; app. A). Approximately $8 \%$ of zircons have ages similar to those of the midcontinent and Central Plains orogens, and $4 \%$ of zircons are consistent with the Superior (peak at $2775 \mathrm{Ma}$ ) and older Archean (peak at $2920 \mathrm{Ma}$ ) provinces. Among the young zircon populations $(<500 \mathrm{Ma}), 5 \%$ are con- 
sistent with the age of Taconic magmatism (peaks at 425 and $480 \mathrm{Ma}$ ), and $2 \%$ of zircons have ages similar to those of the Acadian orogeny. Zircons of Gondwanan affinity in Alleghanian strata include $2 \%$ with Pan-African ages and $1 \%$ with Trans-Amazonian/Eburnean crust ages. The main difference between Alleghanian and Acadian samples is the relative increase in abundance of the Ottawan-age populations and relative decrease in abundance of the Paleozoic populations with minor increases of midcontinent and Superior age populations (fig. 6).

\section{Discussion}

Stratigraphic Evolution of Sedimentary Sources. Our data reveal the evolution of sediment provenance in the Appalachian foreland basin during the Taconic through Alleghanian phases of the Appalachian orogeny. Within the dominant Mesoproterozoic and early Neoproterozoic age populations generally associated with the Grenville orogeny, the Shawinigan signal became progressively smaller while the Ottawan signal increased during the time period recorded by our samples. The progressive upward-younging of Grenville-aged detrital zircons is coupled with a decrease in abundance of zircons with ages consistent with the GraniteRhyolite province. Simultaneously, the population of Paleozoic zircons decreases stratigraphically upward in the Acadian and the Alleghanian samples, and the population of Archean zircons generally increases in Alleghanian samples (figs. 5, 6). Do the systematic waning and waxing of these zircon populations simply indicate depletion of sources in the Shawinigan and Granite-Rhyolite provinces? Or do they reflect new exhumation of basement as the position of thrusting migrated through the larger Grenville basement during the various phases of the Appalachian orogeny?

Previous Appalachian detrital zircon studies generally agree that Paleozoic zircons are derived from the Appalachian orogenic hinterland but suggest that the immediate source of Grenville-age and older zircons is not well constrained. Many studies interpret Grenville-age and older zircons in the Appalachian synorogenic clastic wedges as being derived through recycling of intermediate units such as passive margin successions that were mainly fed from Laurentian provinces through northeastward or southeastward dispersal systems in the central and southern Appalachians (Gehrels et al. 1995; McLennan et al. 2001; Thomas et al. 2004; Becker et al. 2005), although some workers emphasize the possibility of direct derivation of pre-Grenville zircons from distal cratonic sources through a north- ern axial river system (Robinson and Prave 1995; Thomas et al. 2004).

Paleocurrent directions in the Taconic through Alleghanian foreland strata vary, but southwestern and southeastern sources are dominant in Taconic clastic wedges (e.g., Austin Glen Formation: Power and Garver 2004), while southeastern or eastern sources are predominant in Silurian (e.g., Thorold and Grimsby sandstones: Lundegard 1979; Tuscarora Formation: Whisonant 1977) through Mississippian strata (e.g., Upper Devonian Brallier Formation: Lundegard 1979; Lower Mississippian Price Formation: Murphy and Kammer 2001). These general trends of paleocurrent data appear to indicate derivation from orogenic hinterland sources to the east for the Taconic through Alleghanian foreland strata rather than distal craton sources to the north and west.

The relative increase in abundance of Ottawan and Archean zircons in our Alleghanian samples resemble the distribution of detrital zircons collected from passive margin successions (Neoproterozoic Unicoi and Cambrian Erwin formations) that displays the dominance of Ottawan-age zircons and occurrence of Granite-Rhyolite provinceage and Archean zircons (Eriksson et al. 2004). Thus, in light of these similarities and paleocurrent considerations, we interpret the similar distribution of zircon ages between the passive margin succession and our Alleghanian strata to be the result of exhumation of Grenville basement and Neoproterozoic-early Ordovician passive margin strata during the Alleghanian phase, which are well documented to contain significant sediment populations that presumably derived from the older cratonic interior provinces (Robinson and Prave 1995; Thomas et al. 2004).

Within the Grenville-age zircon populations, the Shawinigan signal (peaks at 1173 and $1176 \mathrm{Ma}$ ) progressively decreases in the Taconic to Alleghanian foreland basin strata and is replaced by an increasing abundance of the younger Ottawan signal (peaks at 1055-1068 Ma), with its greatest abundance in the Alleghanian samples (figs. 5, 6). McLennan et al. (2001) found a similar stratigraphic progression as that revealed in our data, such that the mean ages of Grenville-age zircon becomes younger stratigraphically upward from passive margin (Poughquag Quartzite, New York) through Taconic foreland basin strata (Austin Glen member of the Normanskill Formation and the Shawangunk Formation, New York). McLennan et al. (2001) interpreted that the evolution of detrital zircons represents more distal (northwestern) Grenville provinces for the passive margin strata and the 
more proximal (southeastern) Grenville sources for younger Taconic strata.

The upward-younging age progression of detrital zircons in our Taconic through Alleghanian samples may represent reverse unroofing resulting from multiple phases of sediment recycling. Clastic sedimentary rocks often record the progressive unroofing of stratigraphy in the source area, which typically yields a normal unroofing sequence containing framework grains in inverted stratigraphic order in comparison to the source area. If these derived sedimentary strata are subsequently uplifted in the frontal parts of the orogen by further evolution of the mountain belt, they may become the dominant source for the foreland basin at the expense of the more hinterland sources, resulting in reinversion of preexisting unroofing sequences, thereby yielding a reverse unroofing sequence. Although the Grenville rocks are not layered, the multiple phases of the Grenville orogeny were first recognized on the basis of different deformation and magmatism patterns below and above the late Mesoproterozoic Flinton Group (Tollo et al. 2004 ). As a result, it may be possible to interpret progressive unroofing of the Grenville rocks through an examination of the Grenville-aged zircons in the Appalachian foreland basin. Therefore, the youngingupward age progression in our samples may represent a reverse unroofing history, in which case the Grenville zircons in the Taconic to Alleghanian strata should have experienced at least two cycles of sediment recycling. One challenge in detritalzircon geochronology is that many sediments are themselves derived from preexisting sedimentary rocks and the process of multiple recycling is not detectable because the $\mathrm{U}-\mathrm{Pb}$ age provides information pertaining only to the initial source (McLennan et al. 2001; Fedo et al. 2003). The younging-upward age progression in our samples suggests the possibility that vertical evaluation of detrital zircon age distributions may provide insight into the number of times that sediments recycled.

In addition to the aforementioned evolution of Mesoproterozoic and early Neoproterozoic detritalzircon age populations, the presence/absence and abundance of Paleozoic zircon populations vary between the Acadian and Alleghanian foreland basin strata. An abrupt increase in the abundance of $\mathrm{Pa}$ leozoic zircons occurs between the Frasnian ( 375$385 \mathrm{Ma})$ to earliest Famennian ( 368-375 Ma) Foreknobs Formation (Hughes 2001) and the Pragian ( 407-411 Ma) Oriskany formations (Tucker et al. 1998; Ver Straeten 2004), which approximately coincides with the transition from the post-Taconic orogenic quiescence to the Acadian orogeny (figs. 2, 5; table 1; Fichter 1986; Ver Straeten 2008). We interpret these results to indicate orogenic exhumation and incorporation of preexisting magmatic belts (i.e., Taconic belt for the Acadian clastic wedges; Taconic and Acadian belts for the Alleghanian clastic wedges) into the sediment production and deposition systems of the Appalachian orogen and foreland basin. These Paleozoic zircons are more abundant in Acadian clastic wedges than in Alleghanian clastic wedges, and they decrease in abundance stratigraphically upward within the Alleghanian clastic wedges (figs. 5, 6). This progressive decrease of Paleozoic zircons suggests that a geographical barrier may have developed between Paleozoic magmatic arcs and the Alleghanian foreland basin as the Alleghanian deformation exhumed the Grenville basement. This interpretation is also consistent with petrographic data from Acadian and Alleghanian sandstones wherein abundant metamorphic lithic fragments and mica and the relative deficiency of extrabasinal lithic fragments indicate exhumation of deep crust (Eriksson et al. 2004).

Taconic Accretion. The age distribution of detrital zircons in the Ashgillian ( 439-443 Ma) Oswego Formation is significantly different from that of the Caradoc ( 449-450 Ma) Fincastle Member of the Martinsburg Formation, although both units are widely considered to have been deposited during the Taconic orogeny (fig. 5; table 1). The zircon age distribution in the Oswego Formation is very broad, ranging from 460 to $3300 \mathrm{Ma}$, whereas zircon ages in the Fincastle Member more narrowly cluster between 1010 and $2750 \mathrm{Ma}$ (fig. 5). The Oswego Formation sample contains 1900- to 2100-Ma zircons and 670-Ma zircons. The combination of those zircon ages has been interpreted as derivation from a source with Gondwanan affinity (Heatherington et al. 1997; Murphy and Hamilton 2000; Steltenpohl et al. 2001). Moreover, Grenville and Granite-Rhyolite age zircons (peaks at 1109, 1163, and $1345 \mathrm{Ma}$ ) in the Oswego Sandstone are common to other Taconic foreland samples, but provenance components with 460-Ma zircon ages are absent in other Taconic foreland samples including our sample from the Fincastle Member of the Martinsburg Formation (Gray and Zeitler 1997; Cawood and Nemchin 2001; McLennan et al. 2001; Eriksson et al. 2004). Central Plains and midcontinent zircons ( 1600-1800 Ma) in the Oswego sample also reveal a larger relative abundance than those in many other Taconic foreland samples (McLennan et al. 2001; Eriksson et al. 2004). The differences of detrital zircon age populations between the Oswego 
Formation and the Fincastle Member suggest that they are derived from different sources. This possibility is further supported by complementary petrologic and sedimentological studies that indicate the depositional environment of Oswego Sandstone was a fluvio-deltaic system sourced from the eastern hinterland, whereas the Fincastle Member of the Martinsburg Formation was deposited in a submarine fan system that contributed sediment from southeastern sources (Walker 1978; Fichter and Diecchio 1986).

Many paleogeographic and tectonic reconstructions have positioned peri-Gondwanan terranes and the west Gondwanan cratons of South America near or adjacent to the eastern Laurentian margin after rifting of Rodinia (Dalziel 1997; Karlstrom et al. 2001; Hatcher et al. 2004). The Dahlonega terrane of North Carolina, which is located between the western and eastern Blue Ridge provinces, was one such peri-Gondwanan terrane, and it recorded the Neoproterozoic and Paleozoic tectonic history of opening and subduction of the Iapetus Ocean (fig. 1 ; Bream et al. 2004). Composed of immature siliciclastic metasediments intruded by $440-470-\mathrm{Ma}$ mafic and magmatic arc rocks, the Dahlonega terrane is generally interpreted as a short-lived backarc basin (Spell and Norrell 1990; Berger et al. 2001). On the basis of detrital zircon data obtained from the Otto Formation in the Dahlonega terrane together with structural relationships within the Blue Ridge, Bream et al. (2004) suggested that the Dahlonega terrane was sourced from a Grenville belt in western Gondwana and later accreted to the Laurentian margin during the Taconic or Acadian orogenies. The age distribution of detrital zircons known from the Dahlonega terrane resembles our data from the Oswego Sandstone in that both contain age populations similar to western Gondwanan components at $\sim 600-900 \mathrm{Ma}$ and $\sim 1600$ $2100 \mathrm{Ma}$, and so we interpret the Oswego Sandstone to contain sediments potentially recycled from the Dahlonega terrane.

Another sediment source of known Gondwanan affinity in the southern central Appalachians is the Carolina terrane, which accreted to the eastern margin of Laurentia during Appalachian orogenesis (e.g., Horton et al. 1989), although the precise timing of accretion is uncertain. If the Carolina terrane was accreted to the eastern margin of Laurentia during the Late Ordovician, it could have been a source for the Oswego Formation. Single-grain zircon ages collected from the Aaron and Uwharrie Formations of the Carolina terrane range from $\sim 510$ to $620 \mathrm{Ma}$ (Samson et al. 2001; Eriksson et al. 2004), whereas xenocrystic zircon ages cluster at $\sim 1000$,
2100, and $2500 \mathrm{Ma}$ (Ingle et al. 2003). However, the correlation of detrital-zircon ages from the Carolina terrane with zircons in the Oswego Sandstone is comparatively weak, such that there are no zircons with ages between $\sim 620$ and $510 \mathrm{Ma}$, nor ages of 2100 Ma. Hence, the Dahlonega terrane currently appears to be the best candidate for the source of the non-Laurentian zircons contained in the Oswego Sandstone.

Acadian Accretion. In our view, the occurrence of zircons with unambiguous Gondwanan affinity (i.e., 510-680- and 1900-2100-Ma zircons) along with the sudden increase in abundance of Paleozoic detrital zircons in the Devonian-aged Acadian clastic wedges indicate an important terrane accretion event (figs. 5, 6).

Significant numbers of Paleozoic zircons have been identified in the foreland basin strata of the central Appalachians including the Catskill "red beds" of the lower Walton Formation in New York (McLennan et al. 2001) and the Pottsville Formation of Pennsylvania (Gray and Zeitler 1997), but they have only rarely been reported from the southern Appalachian foreland basin (e.g., Cloyd Conglomerate, Virginia: Eriksson et al. 2004). However, in our Acadian clastic wedge samples, abundant zircons younger than $500 \mathrm{Ma}$ start to appear beginning with the Foreknobs Formation. These Paleozoic zircons comprise an average of $13 \%$ of the total zircon population (peak at $451 \mathrm{Ma}$ ), which were presumably derived from magmatic rocks associated with Acadian and Taconic orogenesis in the Appalachian hinterland (figs. 6, 7; Excel data file). The abundance $(11 \%)$ of $450-\mathrm{Ma}$ zircons in our Devonian samples indicates that Taconic magmatic and metasedimentary rocks were important sources of the Acadian foreland basin sediment in West Virginia and Virginia. Synorogenic zircons $(3 \%)$, which are consistent with Acadian volcanism as represented by $\sim 390-417-\mathrm{Ma} \mathrm{K}-$ bentonites that occur pervasively in the central and southern Appalachians (Ver Straeten 2004), also indicate that some parts of the Appalachian foreland basin succession preserve sediment derived directly from contemporaneous orogenic activity.

Trans-Amazonian/Eburnean and Brasiliano/PanAfrican zircons first appear in the $368-385-\mathrm{Ma}$ Foreknobs Formation (figs. 5-7). The Trans-Amazonian/Eburnean ( 1900-2200 Ma) zircons are few but persistent in all Acadian clastic wedge samples, with three grains in the Foreknobs Formation, two grains in the Chemung Formation, two grains in the Grainger Formation, and one grain in the Price Formation (fig. 7; Excel data file). Brasiliano/PanAfrican ( 510-680 Ma) zircons are present with 


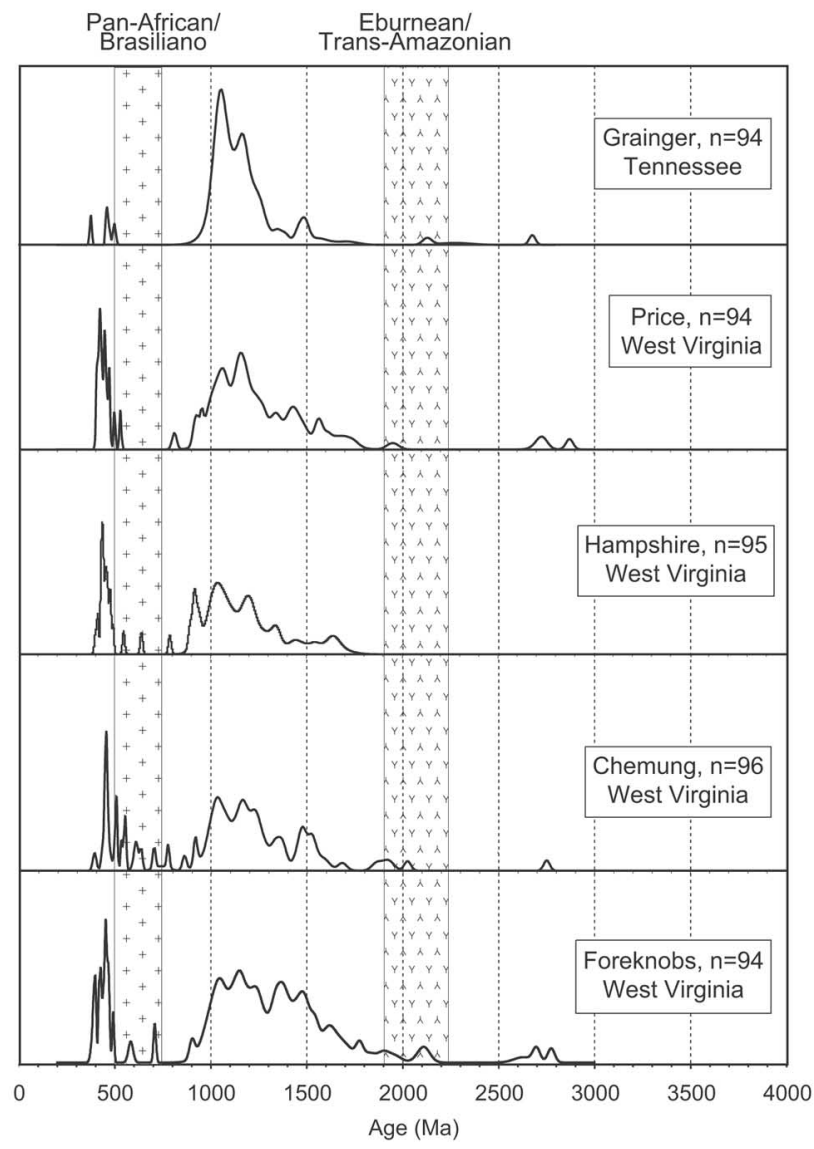

Figure 7. Detrital-zircon age probability plots from Acadian clastic wedges.

seven grains in the Chemung Formation, two grains in the Foreknobs Formation, two grains in the Hampshire Formation, and one grain in the Price Formation (fig. 7; Excel data file).

These Gondwanan zircon peaks in our Devonian samples are temporally correlative to zircon ages in the Carolina terrane $(\sim 430,540$, and $600 \mathrm{Ma}$, with small populations of zircons from 1900-2200 and 2700-2900 Ma), where peak metamorphic events occurred between $\sim 535$ and $538 \mathrm{Ma}$ at the time of the Brasiliano/Pan-African orogeny (Dennis 2007), and later overprinted by amphibolite and granulite facies metamorphism from $~ 350$ to 360 $\mathrm{Ma}$ in the western Carolina terrane (Hatcher 2005). Dennis (2007) interpreted the 350-360-Ma metamorphism as related to dextral shear in the eastern Laurentian transform boundary that may have existed during the Devonian-Mississippian transition. Considering the first appearance of Gondwanan zircons in the Acadian clastic wedge samples, we interpret accretion of the Carolina terrane to have occurred after deposition of the Pra- gian ( 408-411 Ma) Oriskany Formation and before deposition of the Frasnian to the earliest Famennian ( 368-385 Ma) Foreknobs Formation. For some, the Acadian orogeny is considered to consist of as many as four separate large-scale cycles of tectonism from the beginning of the Early Devo$\operatorname{nian}(\sim 410 \mathrm{Ma})$ to the early Mississippian ( 340 Ma) in the southern and central Appalachians (Ettensohn 1985; Bradley and Hanson 1989). The accretion of Carolina terrane, which appears to have occurred between $\sim 385$ and $408 \mathrm{Ma}$, may have caused one of the Acadian orogenic phases.

Middle Mississippian Onset of Alleghanian Orogeny. Detrital-zircon age signatures in our Mississippian samples record a sediment provenance shift with respect to underlying strata. In comparison to Devonian to early Mississippian samples wherein the proportions of Shawinigan and Ottawan age zircons are similar, the population of Ottawan-age zircons increases in upper Mississippian (upper Visean and Serpukhovian) samples, contemporaneous with an increase in the relative abundance of midcontinent- and Superior-age zircons (figs. 6, 8).

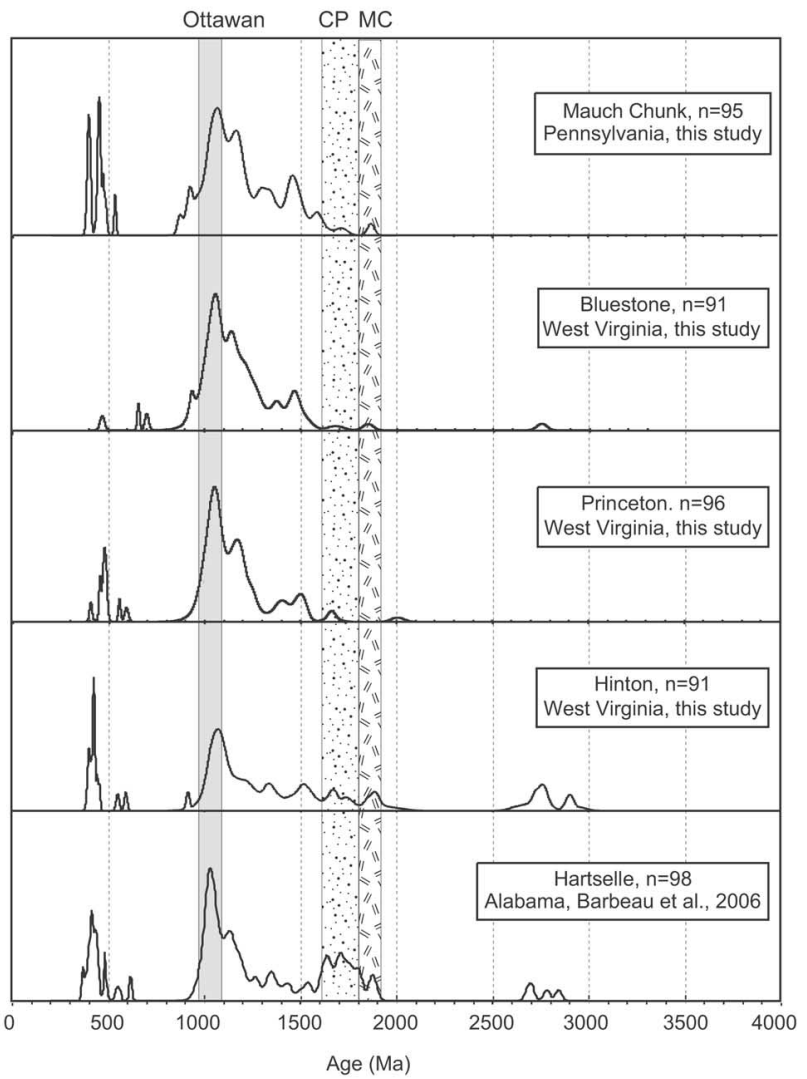

Figure 8. Detrital-zircon probability plots from Alleghanian clastic wedges. Same abbreviations as in figure 5 . 
The combination of abundant zircons from the Ottawan phase of the Grenville orogen with older Laurentian crustal components in our Mississippian samples is similar to the zircon age distributions found in Neoproterozoic and lower Paleozoic passive margin strata of eastern Laurentia (Gleason et al. 2002; Thomas et al. 2004). Thus, we interpret that the passive margin succession was exhumed by the Alleghanian orogeny in the Valley and Ridge fold-thrust belt and parts of the crystalline core of the orogen, thereby providing recycled cratonic and other sediment to the foreland basin as has been previously interpreted in Pennsylvanian foreland basin samples (Thomas et al. 2004; Becker et al. 2005). However, the depositional ages of our samples containing this recycled signature range from the late Visean to Serpukhovian (Excel data file), suggesting that the Alleghanian orogeny may have initiated in the Visean, consistent with interpretation of detrital-zircon data from the middle Mississippian Hartselle Sandstone of northern Alabama (fig. 8: Barbeau et al. 2006; Russell 2006) and Visean Ar-Ar cooling ages from the western Blue Ridge (Hames et al. 2007). Together these results suggest a middle Mississippian onset of the Alleghanian orogeny: 20 m.yr. or more earlier than the commonly accepted date.

As indicated in figure 8, there is a greater abundance of 1600-1800-Ma zircons in the Hartselle Sandstone sample of northern Alabama than in the Mississippian samples reported herein. In light of the Central Plains orogen's position to the southwest of the Appalachian foreland basin, the higher proportions of Central Plains orogen zircons in the Hartselle Sandstone appear to reflect the variable distances from the sources (figs. 1, 3, 5). Hence, we interpret that the detrital-zircon signature of the Hartselle Sandstone may reflect the sedimentary dispersal processes associated with deposition related to the late Paleozoic Ouachita orogeny of southern North America (Thomas 1995).

\section{Conclusions}

1. U-Pb ages of detrital zircons collected from Ordovician to Mississippian foreland basin strata in the southern and central Appalachians (West Virginia, Virginia, Tennessee, and Pennsylvania) include the usually prominent population of grains aged $\sim 1100-1400-\mathrm{Ma}$ and presumably derived from the Grenville province, but they also contain major components of zircons from $\sim 430$ to $700 \mathrm{Ma}$, along with lesser populations of zircons with ages of 1900-2200 and 2700-2900 Ma.

2. The age distribution of detrital zircons in our samples records the relationship between orogenic activity and provenance of foreland sediments deposited in response to the Appalachian orogeny. The age distribution of detrital zircons is relatively wide in Taconic, Acadian, and Alleghanian clastic wedges, ranging from the middle Paleozoic to Archean ages, whereas the age distribution is narrow in pre- or interorogenic strata, typically clustering between 900 and $1800 \mathrm{Ma}$. These data indicate that Acadian and Alleghanian orogenic activity exhumed and exposed preexisting hinterlands, including parts of the Taconic orogenic belt, and developed new sedimentary dispersal systems that provided various sources to the foreland basin during orogenic activity. In contrast, the basin was fed from less diverse sediment sources during orogenic quiescence in the Silurian.

3. Samples from Taconic clastic wedges reveal high proportions of Shawinigan ( 1160-1190 Ma) and Granite-Rhyolite zircons $(\sim 1300-1500 \mathrm{Ma})$. Samples in Acadian clastic wedges are characterized by large populations of Paleozoic zircons and the occurrence of Pan-African/Brasiliano ( 500$700 \mathrm{Ma}$ ) and Eburnean/Trans-Amazonian ( 1900$2250 \mathrm{Ma}$ ) zircons. Samples from Alleghanian clastic wedges are representative of large amounts of Ottawan zircons ( 980-1080 Ma), an increased abundance of distal craton zircons, and a decreased abundance of Paleozoic zircons. The general pattern of detrital-zircon age distribution indicates that distal sources from Grenville and associated Granite-Rhyolite provinces are the most important sources during the Taconic orogeny, but frontal orogen and orogenic hinterland sources from Paleozoic magmatic arcs and associated metasedimentary rocks comprise more important components in sedimentary record during the Acadian and Alleghanian orogenies.

4. There is a stratigraphic evolution of Grenvilleage sources recorded in the foreland basin from the Taconic through Alleghanian orogenies. The Shawinigan signal progressively decreased while the Ottawan signal increased through the Taconic to Alleghanian orogenies. We interpret the youngingupward age progression to represent the reverse unroofing history of the Appalachians, suggesting at least two cycles of Grenville-age zircon recycling.

5. The different age distribution of detrital zircons between the Oswego and Fincastle formations in Taconic clastic wedges may be attributed to changes in sources associated with accretion of the Dahlonega terrane.

6. The appearance of abundant Paleozoic detrital zircons in Acadian synorogenic clastic wedges indicates that: $(a)$ the Taconic hinterland, which con- 
sisted of recycled material and possible exposure of Taconic-aged plutons, provided a significant amount of erosional detritus to the Appalachian foreland basin, and $(b)$ a significant terrane accretion event to the Laurentian margin occurred in Devonian time.

7. The Foreknobs and Chemung formations in Acadian clastic wedges contain zircons with ages of 385-400 Ma, indicating that these detrital zircons record contemporaneous magmatic activity.

8. The presence of Pan-African/Brasiliano and Eburnean/Trans-Amazonian zircons in the Acadian clastic wedges supports 385-408-Ma (Devonian) accretion of the Carolina terrane.

9. The decrease of Paleozoic detrital zircons coupled with an increase of Ottawan- and Superior-age zircons in Alleghanian clastic wedges indicates that the passive margin succession and Grenville basement were exhumed by thrusting associated with the Alleghanian orogeny, which provided erosional detritus to the foreland basin while preventing sediment input from Taconic hinterland sources through the development of a topographic barrier.
10. The detrital-zircon signatures in Mississippian clastic wedges from Pennsylvania to Alabama imply a Visean onset of the Alleghanian orogeny.

\section{A C K N O W LE D G MENTS}

David Gombosi is gratefully acknowledged for accompanying us on our sampling trip, for assistance with sample preparation, and for helpful manuscript reviews. We thank Victor Valencia for operation and assistance on laser ablation-multicollector-inductively coupled plasma-mass spectrometry at the Arizona LaserChron Center of the University of Arizona. This research was supported by the American Associated Petroleum Geologists Grant-In-Aid program, the Geological Society of America Graduate Student Grant program, and the Magellan Scholar program of the University of South Carolina. Matt Kohn and Dwight Bradley provided valuable reviews that significantly improved the manuscript.

\section{R E F E R E N C E S C I T E D}

Aleinikoff, J. N.; Burton, W. C.; Lyttle, P. T.; Nelson, A. E.; and Southworth, C. S. 2000. U-Pb geochronology of zircon and monazite from Mesoproterozoic granitic gneisses of the northern Blue Ridge, Virginia and Maryland, U.S.A. Precambrian Res. 99:113-146.

Aleinikoff, J. N.; Zartman, R. E.; Rankin, D. W.; and Burton, W. C. 1995. U-Pb ages of metarhyolites of the Catoctin and Mt. Rogers formations, central and southern Appalachians: evidence of two pulses of Iapetan rifting. Am. J. Sci. 295:428-454.

Amato, J. M.; Boullion, A. O.; Serna, A. M.; Sanders, A. E.; Farmer, G. L.; Gehrels, G. E.; and Wooden, J. L. 2008. Evolution of the Mazatzal Province and the timing of the Mazatzal orogeny: insights from U-Pb geochronology and geochemistry of igneous and metasedimentary rocks in southern New Mexico. Geol. Soc. Am. Bull. 120:8-346

Badger, R. L., and Sinha, A. K. 1988. Age and Sr isotope signature of the Catoctin volcanic province: implications for subcrustal mantle evolution. Geology 16: 692-695.

Barbeau, D. L.; Russell, M.; Brenneman, E.; and Gehrels, G. 2006. Detrital-zircon geochronology of the southern Appalachian foreland basin and its source rocks. Geol. Soc. Am. Abstr. Program 38:6.

Becker, T. P.; Thomas, W. A.; Samson, S. D.; and Gehrels, G. E. 2005. Detrital zircon evidence of Laurentian crustal dominance in the lower Pennsylvanian deposits of the Alleghanian clastic wedge in eastern North America. Sediment. Geol. 182:59-86.

Bennett, V. C., and DePaolo, D. J. 1987. Proterozoic crustal history of the western United States as determined by neodymium isotopic mapping: Geol. Soc. Am. Bull. 99:674-685.

Berg, T. M.; Mclnerney, M. K.; Way, J. H.; and MacLachlan, D. B. 1983. Stratigraphic correlation chart of Pennsylvania. General geology report 75. Middletown, Pennsylvania Bureau of Topographic and Geologic Survey.

Berger, S.; Cochrane, D.; Simons, K.; Savov, I.; Ryan, J. G.; and Peterson, V. I. 2001. Insights from rare earth elements into the genesis of the Buck Creek complex, Clay County, NC. Southeast. Geol. 40:201-212.

Black, L. P.; Kamo, S. L.; Allen, C. M.; Davis, D. W.; Aleinikoff, J. N.; Valley, J. W.; Mundil, R.; et al. 2004. Improved ${ }^{206} \mathrm{~Pb} /{ }^{238} \mathrm{U}$ microprobe geochronology by the monitoring of a trace-element-related matrix effect: SHRIMP, ID-TIMS, ELA-ICP-MS and oxygen isotope documentation for a series of zircon standards. Chem. Geol. 205:115-140.

Bradley, D. C. 1989. Taconic plate kinematics as revealed by foredeep stratigraphy, Appalachian Orogen. Tectonics 8:1037-1049.

- 2008. Passive margins through earth history. Earth Sci. Rev. 91:1-26.

Bradley, D. C.; Tucker, R. D.; Lux, D. R.; Harris, A. G.; and McGregor, D. C. 2000. Migration of the Acadian Orogen and foreland basin across the Northern Appalachians of Maine and adjacent areas. U.S. Geol. Surv. Prof. Pap. 1623. 64 p.

Bream, B. R.; Hatcher, R. D.; Miller, G. F., Jr.; and Fullagar, P. D. 2004. Detrital zircon ages and $\mathrm{Nd}$ isotopic 
data from the southern Appalachian crystalline core, Georgia, South Carolina, North Carolina, and Tennessee: new provenance constrains for part of the Laurentian margin. In Tollo, R. P., Corriveau, L., McLelland, J., and Bartholomew, M. J., eds. Proterozoic tectonic evolution of the Grenville orogen in North America. Geol. Soc. Am. Mem. 197:459-475.

Brett, C. E.; Goodman, W. M.; and LoDuca, S. T. 1990. Sequence, cycles, and basin dynamics in the Silurian of the Appalachian Foreland Basin. Sediment. Geol. 69:191-244.

Cardwell, D. H.; Erwin, R. B.; and Woodward, H. P. 1968. Geologic map of West Virginia.

Castle, J. W. 1998. Regional sedimentology and stratal surfaces of a Lower Silurian clastic wedge in the Appalachian foreland basin. J. Sediment. Res. 68:12011211.

2001. Foreland-basin sequence response to collisional tectonism. Geol. Soc. Am. Bull. 113:801-812.

Cawood, P. A.; McCausland, P. J. A.; and Dunning, G. R. 2001. Opening Iapetus: constraints from the Laurentian margin in Newfoundland. Geol. Soc. Am. Bull. 113:443-453.

Cawood, P. A., and Nemchin, A. A. 2001. Paleogeographic development of the eastern Laurentian margin: constraints from U-Pb dating of detrital zircons from the northern Appalachians. Geol. Soc. Am. Bull. 113:1234-1246.

Coler, D. G., and Samson, S. D. 2000. Characterization of the Spring Hope and Roanoke Rapids terranes, southern Appalachians; a U-Pb geochronologic and Nd isotopic study. Geol. Soc. Am. Abstr. Program 32: $11-12$.

Coler, D. G.; Wortman, G. L.; Samson, S. D.; Hibbard, J. P.; and Stern, R. 2000. U-Pb geochronologic, Nd isotopic, and geochemical evidence for the correlation of the Chopawamsic and Milton Terranes, Piedmont Zone, Southern Appalachian Orogen. J. Geol. 108: 363-380.

Dalziel, I. W. D. 1997. Overview: Neoproterozoic-Paleozoic geography and tectonics: review, hypothesis, environmental speculations. Geol. Soc. Am. Bull. 109: 16-42.

Davis, M. W., and Ehrlich, R. 1974. Late Paleozoic crustal composition and dynamics in the southeastern United Statues. In Briggs, G., ed. Carboniferous of the southeastern United States. Geol. Soc. Am. Spec. Pap. 148: $171-185$.

Davydov, V.; Wardlaw, B. R.; and Gradstein, F. M. 2004. The Carboniferous period. In Gradstein, F. M., Ogg, J. G., and Smith, A., eds. A geologic time scale. New York, Cambridge University Press, p. 222-248.

DeCelles, P. G., and Giles, K. A. 1996. Foreland basin systems. Basin Res. 8:105-123.

Dennis, A. J. 2007. Cat Square basin, Catskill clastic wedge: Silurian-Devonian orogenic events in the central Appalachians and the crystalline southern Appalachians. In Sears, J. W.; Harms, T. A.; and Evenchick, C. A., eds. Whence the mountains? inquiries into the evolution of orogenic systems. A volume in honor of Raymond A. Price. Geol. Soc. Am. Spec. Pap. 433:313-329.

Diecchio, R. J. 1986. Taconian clastic sequence and general geology in the vicinity of the Allegheny Front in Pendleton County, West Virginia. In Neathery, T. L., ed. Centennial field guide: southeastern section. Geol. Soc. Am. 6:85-90.

Drake, A. A.; Sinha, A. K.; Laird, J.; and Guy, R. E. 1989. The Taconic orogen. In Hatcher, R. D., Jr., Thomas, W. A., and Viele, G. W., eds. The Appalachian-Quachita Orogen in the United States (Geology of North America, Vol. F-2). Boulder, CO, Geol. Soc. Am., p. 101-177.

Eriksson, K. A.; Campbell, I. H.; Palin, J. M.; Allen, C. M.; and Bock, B. 2004. Evidence for multiple recycling in Neoproterozoic through Pennsylvanian sedimentary rocks of the Central Appalachian Basin. J. Geol. 112:261-276.

Ettensohn, F. R. 1985. The Catskill Delta Complex and the Acadian Orogeny: a model. In Woodrow, D. L., and Sevon, W. D., eds. The Catskill Delta. Geol. Soc. Am. Spec. Pap. 201:39-49.

- 1991. Flexural interpretation of relationships between Ordovician tectonism and stratigraphic sequences, central and southern Appalachians, U.S.A. In Barnes, C. R., and Williams, S. H., eds. Advances in Ordovician geology. Geol. Surv. Can. 90-9:213-224.

1994. Tectonic control on formation and cyclicity of major Appalachian unconformities and associated stratigraphic sequences. In Dennison, J. M., and Ettensohn, F. R. eds. Tectonic and eustatic controls on sedimentary cycles, concepts in sedimentary paleontology. SEPM 4:217-242.

Faill, R. T. 1985. The Acadian Orogeny and Catskill Delta. In Woodrow, D. L.; and Sevon, W. D., eds. The Catskill Delta. Geol. Soc. Am. Spec. Pap. 201:15-37.

Fedo, C.; Sircombe, K.; and Rainbird, R. 2003. Detrital zircon analysis of the sedimentary record. In Hanchar, J. M., and Hoskin, P. O., eds. Zircon: experiments, isotopes, and trace element investigation. Reviews in Mineralogy and Geochemistry 53. Washington, DC, Mineralogical Society of America, p. 277-303.

Fichter, L. S. 1986. The Catskill clastic wedge (Acadian Orogeny) in eastern West Virginia. In Neathery, T. L. ed. Centennial field guide: southeastern section. Geol. Soc. Am. 6:91-96.

Fichter, L. S., and Diecchio, R. J. 1986. The Taconic sequence in the northern Shenandoah Valley. In Neathery, T. L. ed. Centennial field guide: southeastern section. Geol. Soc. Am. 6:73-78.

Gaudette, H. E.; Vitrac-Michard, A.; and Allegre, C. J. 1981. North American Precambrian history recorded in a single sample: high-resolution U-Pb systematics of the Potsdam sandstone detrital zircons, New York State. Earth Planet. Sci. Lett. 54:248-260.

Gehrels, G. E.; Dickinson, W. R.; Ross, G. M.; Stewart, J. H.; and Howell, D. G. 1995. Detrital zircon reference for Cambrian to Triassic miogeoclinal strata of western North America. Geology 23:831-834.

Gehrels, G. E.; Valencia, A.; and Pullen, A. 2006. Detrital 
zircon geochronology by laser ablation multicollector ICPMS at the Arizona LaserChron Center. In Olszewski, T. ed. Geochronology: emerging opportunities. Paleontol. Soc. Pap. 12:67-76.

Geraldes, M. C., Van Schmus, W. R., Condie, K. C., Bell, S., Teixeira, W., and Babinski, M. 2001. Proterozoic geologic evolution of the SW part of the Amazonian Craton in Mato Grosso state, Brazil. Precambrian Res. 111:91-128.

Gleason, J. D.; Finney, S. C.; and Gehrels, G. E. 2002. Paleotectonic implications of a Mid- to Late-Ordovician provenance shift, as recorded in sedimentary strata of the Ouachita and southern Appalachian Mountains. J. Geol. 110:291-304.

Gray, M. B., and Zeitler, P. K. 1997. Comparison of clastic wedge provenances in the Appalachian foreland using U-Pb ages of detrital zircons. Tectonics 16:151-160.

Hames, W. E.; Tull, J. F.; Barbeau, D. L., Jr.; McDonald, W. M.; and Steltenpohl, M. G. 2007. Laser ${ }^{40} \mathrm{Ar} /{ }^{39} \mathrm{Ar}$ ages of muscovite and evidence for Mississippian (Visean) deformation near the thrust front of the southwestern Blue Ridge province. Geol. Soc. Am. Abstr. Program 39:78.

Hammer, S. 1988. Ductile thrusting at mid-crustal level, southwestern Grenville Province. Can. J. Earth Sci. 25:1049 1059 .

Hanson, R. E.; Wilson, T. J.; and Munyanyiwa, H. 1994. Geologic evolution of the Neoproterozoic Zambezi orogenic belt in Zambia. J. African Earth Sci. 18:135150.

Hartmann, L. A. 2002. The Mesoproterozoic supercontinent Atlantica in the Brazilian shield: review of geological and $\mathrm{U}-\mathrm{Pb}$ zircon and $\mathrm{Sm}-\mathrm{Nd}$ isotopic evidence. Gondwana Res. 5:157-163.

Hatcher, R. D., Jr. 1987. Tectonics of the southern and central Appalachian internides. Rev. Earth Planet. Sci. 15:337-362.

. 2005. Southern and central Appalachians. London, Elsevier, p. 72-81.

Hatcher, R. D., Jr., and Bream, B. R. 2002. Inner Piedmont geology in the South Mountains-Blue Ridge Foothills and the southwestern Brushy Mountains, central western North Carolina. Annual field trip guidebook. Raleigh, NC, North Carolina Geological Survey, 146 p.

Hatcher, R. D., Jr.; Bream, B. R.; Miller, C. F.; Eckert, J. O., Jr.; Fullagar, P. D.; and Carrigan, C. W. 2004. Paleozoic structure of internal basement massifs, southern Appalachian Blue Ridge, incorporating new geochronologic, $\mathrm{Nd}$ and $\mathrm{Sr}$ isotopic, and geochemical data. In Tollo, R. P.; Corriveau, L.; McLelland, J.; and Bartholomew, M. J., eds. Proterozoic tectonic evolution of the Grenville orogen in North America. Geol. Soc. Am. Mem. 197:525-547.

Hatcher, R. D., Jr.; Thomas, W. A.; Geiser, P. A.; Snoke, A. W.; Mosher, S.; and Wiltschko, D. V. 1989. Alleghanian orogen, In Hatcher, R. D., Jr.; Thomas, W. A.; and Viele, G. W., eds. The Appalachian-Ouachita orogen in the United States (Geology of North America, Vol. F-2), Boulder, CO, Geol. Soc. Am., p. 233-318.
Heatherington, A. L.; Mueller, P. A.; and Wooden, J. L. 1999. Alleghanian plutonism in the Suwannee terrane. Geol. Soc. Am. Abstr. Program 31:A-117.

Heatherington, A. L.; Steltenpohl, M. G.; Yokels, L. S.; and Mueller, P. A. 1997. Ages of detrital zircons from the Pine Mountain and Inner Piedmont terranes and the Valley and Ridge Province: implications for Neoproterozoic tectonics of the southern Laurentian margin. Geol. Soc. Am. Abstr. Program 29:432.

Heumann, M. J.; Bickford, M. E.; Hill, B. M.; McLelland, J. M.; Selleck, B. W.; and Jercinovic, M. J. 2006. Timing of anatexis in metapelites from the Adirondack lowlands and southern highlands: a manifestation of the Shawinigan orogeny and subsequent anorthositemangerite-charnockite-granite magmatism. Geol. Soc. Am. Bull. 118:1283-1298.

Hibbard, J. P.; Stoddard, E. F.; Secor, D. T.; and Dennis, A. J. 2002. The Carolina Zone: overview of Neoproterozoic to early Paleozoic peri-Gondwanan terranes along the eastern flank of the southern Appalachians. Earth Sci. Rev. 57:299-339.

Hibbard, J. P.; Tracy, R. J.; and Henika, W. S. 2003. Smith River allochthon: a southern Appalachian peri-Gondwanan terrane emplaced directly on Laurentia? Geology 31:215-218.

Hoffman, P. F. 1989. Precambrian geology and tectonic history of North America. In Bally, A. W., and Palmer, A. R., eds. Geology of North America: an overview (Geology of North America, Vol. A), Boulder, CO, Geol. Soc. Am. p. 447-512.

- 1999. The break-up of Rodinia, birth of Gondwana, true polar wander and the snowball Earth. J. African Earth Sci. 28:17-33.

Holm, D. K.; Anderson, R.; Boerboom, T. J.; Cannon, W. F.; Chandler, V.; Jirsa, M.; Miller, J.; Schneider, D. A.; Schulz, K. J.; and Van Schmus, W. R. 2007. Reinterpretation of Paleoproterozoic accretionary boundaries of the north-central United States based on a new aeromagnetic-geologic compilation. Precambrian Res. 157:71-79.

Horton, J. W., Jr.; Drake, A. A.; and Rankin, D. W. 1989. Tectonostratigraphic terranes and their Paleozoic boundaries in the central and southern Appalachians. In Dallmeyer, R. D., ed. Terranes in the circumAtlantic Paleozoic orogens. Geol. Soc. Am. Spec. Pap. 230:213-245.

Hughes, G. M. G. 2001. Biostratigraphic correlation of the new Devonian timescale using palynology. Am. Assoc. Petrol. Geol. Bull. 85:2052-2053.

Ingle, S.; Mueller, P. A.; Heatherington, A. L.; and Kozuch, M. 2003. Isotopic evidence for the magmatic and tectonic histories of the Carolina terrane: implications for stratigraphy and terrane affiliation. Tectonophysics 371:187- 211 .

Ingle-Jenkins, S.; Mueller, P. A.; Heatherington, A. L.; and Offield, T. W. 1998. Age and origin of the Uwharrie Formation and Albemarle Group, Carolina slate belt; implications from U-Pb and Sm-Nd systematics. Geol. Soc. Am. Abstr. Program 30:239.

Johnson, M. E. 1987. Extent and bathymetry of North 
American platform seas in the Early Silurian. Paleoceanography 2:185-211.

Johnson, M. E.; Rong, J.; and Yang, X. 1985. Intercontinental correlation by sea-level events in the Early Silurian of North America and China (Yangtze platform). Geol. Soc. Am. Bull. 96:1384-1397.

Jones, P. J. 1996. Carboniferous. In Young, G. C., and Laurie, J. R., eds. An Australian Phanerozoic timescale. Melbourne, Oxford University Press, p. 10-126.

Jordan, T. E. 1995. Retroarc foreland and related basins. In Busby, C. J., and Ingersoll, R., eds. Tectonics of sedimentary basins. Cambridge, MA, Blackwell Science, p. 331-363.

Karlstrom, K. E.; Ahall, K.; Harlan, S. S.; Williams, M. L.; McLelland, J. M.; and Geissman, J. W. 2001. Long lived $(1.8-1.0 \mathrm{Ga})$ convergent orogen in southern Laurentia, its extension to Australia and Baltica, and implications for refining Rodinia. Precambrian Res. 111: 5-30.

Karlstrom, K. E., and Bowring, S. A.. 1988. Early Proterozoic assembly of tectonostratigraphic terranes in southwestern North America. J. Geol. 96:561-576.

Keppie, J. D., and Ortega-Gutierrez, F. 1999. Middle American Precambrian basement; a missing piece of the reconstructed 1-Ga orogen. Geol. Soc. Am. Spec. Pap. 336:199-210.

Knowles, R. R. 1966, Geology of a portion of the Everett 15-minute quadrangle, Bedford County, Pennsylvania. Progress report PR 170. Middletown, Pennsylvania Topographic and Geologic Survey, $90 \mathrm{p}$.

Ludwig, K. J. 2003. Isoplot 3.00. Special Publication 4. Berkeley, CA, Berkeley Geochronology Center, 70 p.

Lundegard, P. D. 1979. Sedimentology and petrology of a prodeltaic turbidite system; the Brallier Formation (Upper Devonian), western Virginia and adjacent areas. MS thesis, University of Cincinnati, $296 \mathrm{pp}$.

Matchen, D. L., and Kammer, T. W. 1994. Sequence stratigraphy of lower Mississippian Price and Borden formation in southern West Virginia and eastern Kentucky. Southeast. Geol. 34:25-41.

Maynard, J. P.; Eriksson, K. A.; and Law, R. D. 2006. The upper Mississippian Bluefield Formation in the central Appalachian basin: a hierarchical sequence-stratigraphic record of a greenhouse to icehouse transition. Sediment. Geol. 192:99-122.

McLelland, J. M.; Bickford, M. E.; Hill, B. M.; Clechenko, C. C., Valley, J. W.; and Hamilton, M. A. 2004. Direct dating of Adirondack massif anorthosite by U-Pb SHRIMP analysis of igneous zircon: implications for AMCG complexes. Geol. Soc. Am. Bull. 116:12991317.

McLennan, S. M.; McDaniel, D. K.; Bock, B.; Compston, W.; and Hemming, S. R. 2001. Detrital-zircon geochronology of Taconian and Acadian foreland sedimentary rocks in New England. J. Sediment. Res. 71: 305-317.

Mezger, K.; Essene, E. J.; van der Piuijm, B. A.; and Halliday, A. N. 1993. U-Pb geochronology of the Grenville Orogen of Ontario and New York: constraints on an- cient crustal tectonics. Contrib. Mineral. Petrol. 114: 13-26.

Millici, R. C., and Witt, W., Jr. 1988. The Appalachian Basin. In Sloss, L. L., ed. Sedimentary cover-North America Craton: U.S. (Geology of North America, Vol. D-2). Boulder, CO, Geol. Soc. Am. 427-469.

Moores, E. M. 1991. Southwest US East Antarctica (SWEAT) connection: a hypothesis. Geology 19:425428.

Mueller, P. A.; Heatherington, A. L.; Wooden, J. L.; Shuster, R. D.; Nutman, A. P. and Williams, I. S. 1994. Precambrian zircons from the Florida basement; a Gondwanan connection. Geology 22:119-122.

Murphy, J. B., and Hamilton, M. A. 2000. Orogenesis and basin development $\mathrm{U}-\mathrm{Pb}$ detrital zircon age constraints on evolution of the late Paleozoic St. Marys basin, central mainland Nova Scotia. J. Geol. 108:5371.

Murphy, S. J., and Kammer, T. W. 2001. Influence of the West Virginia Dome on paleocurrent patterns in the Upper Devonian-Lower Mississippian Price Formation in the Central Appalachians. Am. Assoc. Petrol. Geol. Abstr. 85:1537.

Nyman, M. W.; Karlstrom, K. E.; Kirby, E.; and Graubard, C. M. 1994. Mesoproterozoic contractional orogeny in western North America; evidence from ca. 1.4 Ga plutons. Geology 22:901-904.

Osberg, P. H.; Tull, J. F.; Robinson, P.; Hon, R.; and Butler, J. R. 1989. The Acadian Orogen. In Hatcher, R. D., Jr.; Thomas, W. A.; and Viele, G. W. eds. The AppalachianOuachita Orogen in the United States (Geology of North America, Vol. F-2). Boulder, CO, Geol. Soc. Am., p. 179-232.

Power, L. N., and Garver, J. I. 2004. Depositional response of Ordovician foreland basin turbidites to bathymetry in the frontal thrust of the Taconic thrust wedge. Geol. Soc. Am. Abstr. Program 36:75.

Rankin, D. W.; Tollo, R. P.; Aleinikoff, J. A.; and Ayuso, R. A.1997. Manhattan Prong A-type metagranites with feldspar $\mathrm{Pb}$ isotope affinities to Laurentia and zircon ages of $563 \mathrm{Ma}$ : support for late Neoproterozoic Iapetian rifting. Geol. Soc. Am. Abstr. Program 33:74.

Read, J. F. 1989. Carbonate ramp-to-basin transitions and foreland evolution, Middle Ordovician, Virginia Appalachians. Am. Assoc. Petrol. Geol. Bull. 64:15751612.

Rivers, T. 1997. Lithotectonic elements of the Grenville province: Precambrian Res. 86:117-154.

Robinson, R. A. J., and Prave, A. R. 1995. Cratonal contributions to a "classic" molasse: the Carboniferous Pottsville Formation of eastern Pennsylvania revisited. Geology 23:369-372.

Russell, M. A. 2006. Detrital zircon geochronology of the southern Appalachian foreland basin. MS thesis, Columbia, University of South Carolina, $75 \mathrm{p}$.

Samson, S. D.; Secor, D. T.; and Hamilton, M. A. 2001. Wandering Carolina: tracking exotic terranes with detrital zircons. Geol. Soc. Am. Abstr. Program 33:263.

Santos, J. O. S.; Rizzottoc, G. J.; Potterd, P. E. ; McNaughtone, N. J. ; Matosf, R. S.; Hartmann, L. A.; 
Chemale, F., Jr.; and Quadrosc, M. E. S. 2008. Age and autochthonous evolution of the Sunsas Orogen in West Amazon Craton based on mapping and U-Pb geochronology. Precambrian Res. 165:120-152.

Schofield, D. I.; Horstwood, M. S. A.; Pitfield, P. E. J.; Crowley, Q. G.; Wilkinson, A. F.; and Sidaty, H. C. O., 2006. Timing and kinematics of Eburnean tectonics in the central Reguibat Shield, Mauritania. J. Geol. Soc. Lond. 163:549-560.

Schofield, D. I., and Gillespie, M. R. 2007. A tectonic interpretation of "Eburnean terrane" outliers in the Reguibat Shield, Mauritania. J. African Earth Sci. 4: 179-186.

Secor, D. T., Jr.; Samson, S.; Snoke, A.; and Palmer, A. 1983. Confirmation of the Carolina slate belt as an exotic terrane. Science. 221:649-651.

Sims, P. K. 1996. Early Proterozoic Penokean orogen. In Sims, P. K., and Carter, L. M. H. eds. Archean and Proterozoic geology of the Lake Superior region, USA. U.S. Geol. Surv. Prof. Pap. 1556:28-30.

Sinha, A. K.; Hund, E. A.; and Hogan, J. P. 1989. Paleozoic accretionary history of the North American plate margin (central and southern Appalachians): constraints from the age, origin, and distribution of granitic rocks. In Hillhouse, J. W., ed. Deep structure and past kinematics of accreted terranes. Am. Geophys. Union Geophys. Monogr. 50:219-238.

Spell, T. L., and Norrell, G. T. 1990. The Ropes Creek assemblage: petrology, geochemistry, and tectonic setting of an opiolitic thrust sheet in the southern Appalachians. Am. J. Sci. 290:811-842.

Steltenpohl, M. G.; Heatherington, A. L.; and Mueller, P. A. 2001. Our current understanding of the Grenville event in the southernmost Appalachians, Pine Mountain window, Alabama. Geol. Soc. Am. Abstr. Program 33:29.

Teixeira, W., D'Agrella-Filho, M. S., and Trindade, R. I. 2009. The position of the Amazonian Craton in supercontinents. Gondwana Res. 15:369-407.

Thomas, W. A. 1991. The Appalachian-Ouachita rifted margin of southeastern North America. Geol. Soc. Am. Bull. 103:415-431.

- 1995. Diachronous thrust loading and fault partitioning of the Black Warrior foreland basin within the Alabama recess of the Late Paleozoic AppalachianOuachita Thrust belt. In Dorobek, S. L.; Ross, G. M.; eds. Stratigraphic evolution of foreland basins. SEPM Spec. Publ. 52:111-126.

Thomas, W. A.; Astini, R. A; Mueller, P. A.; McClelland, W. C.; Kamenov, G. A; Allen, J. S; and Hyacinth, L. 2009. Provenance of the middle-late Ordovician clastic wedge in the Argentine Precordillera, Geol. Soc. Am. Abstr. Program 41:20

Thomas, W. A.; Becker, T. P.; Samson, S. D.; and Hamilton, M. A. 2004. Detrital zircon evidence of a recycled orogenic foreland provenance for Alleghanian clastic-wedge sandstones. J. Geol. 112:23-37.

Tucker, R. D.; Bradley, D. C.; Ver Straeten, C. A.; Harris, A. G.; Ebert, J. R.; and McCutcheon, S. R. 1998. New
U-Pb ages and the duration and division of Devonian time. Earth Planet. Sci. Lett. 158:175-186.

Van Schmus, W. R.; Bickford, M. E.; Anderson, J. L.; Bender, E. E.; Anderson, R. R.; Bauer, P. W.; and Robertson, J. M. 1993. Transcontinental Proterozoic provinces. In Reed, J. C., Jr.; Bickford, M. E.; Houston, R. S.; Link, P. K.; Rankin, D. W.; Sims, P. K.; and Van Schmus, W. R., eds. Precambrian: conterminous U. S. (Geology of North America, Vol. C-2), Boulder, CO, Geol. Soc. Am., p. 171-334.

Ver Straeten, C. A. 2004. K-bentonites, volcanic ash preservation, and implications for Early to Middle Devonian volcanism in the Acadian orogen, eastern North America. Geol. Soc. Am. Bull. 116:474-489.

2008. Volcanic tephra bed formation and condensation processes: a review and examination from Devonian stratigraphic sequences. J. Geol. 116:545-557.

Walker, R. G. 1978. Deep-water sandstone facies and ancient submarine fans: models for exploration for stratigraphic traps. Am. Assoc. Petrol. Geol. Bull. 62:932966.

Walsh, G. J., and Aleinikoff, J. N.1999. U-Pb zircon age of metafelsite from the Pinney Hollow Formation: implications for the development of the Vermont Appalachians: Am. J. Sci. 299:157-170.

Wehr, F., and Glover, L., III. 1985. Stratigraphy and tectonics of the Virginia-North Carolina Blue Ridge: evolution of a late Proterozoic-Early Paleozoic hinge zone. Geol. Soc. Am. Bull. 96:285-295.

Williams, H., ed. 1978. Tectonic lithofacies map of the Appalachian orogen. St. Johns Memorial University of Newfoundland, scale 1:1,000,000.

Williams, H., and Hatcher, R. D., Jr. 1983. Appalachian suspect terranes. In Hatcher, R. D., Jr.; Zietz, I.; and Williams, H., eds. Contributions to the tectonics and geophysics of mountain chains. Geol. Soc. Am. Mem. 158:33-54.

Wise, D. U.; Smith, R. C., II; Jercinovic, M. J.; Ganis, G. R.; Onasch, C. M.; Repetski, J. E.; and Williams, M. L. 2007. Tectonic implications of a new $450 \mathrm{Ma}$ monazite date and $\mathrm{T} / \mathrm{P}$ data from the Martic Zone, Pequea "silver" mine, SE Pennsylvania. Geol. Soc. Am. Abstr. Program 39:50.

Whisonant, R. C. 1977. Lower Silurian Tuscarora (Clinch) dispersal patterns in western Virginia. Geol. Soc. Am. Bull. 88:215-220.

Wooden, J. L., and Mueller, P. A. 1988. Pb, Sr, and Nd isotopic compositions of a suite of late Archean, igneous rocks, eastern Beartooth Mountains; implications for crust-mantle evolution. Earth Planet. Sci. Lett. 87:59-72.

Wortman, G. L.; Samson, S. D.; and Hibbard, J. P. 2000. Precise U-Pb zircon constraints on the earliest magmatic history of the Carolina terrane. J. Geol. 108:321338.

Wynn, T. C., Al-Tawil, A., and Read, J. F. 2006. Outcrop analogs for subsurface Mississippian Greenbrier Limestone reservoirs, West Virginia, USA. Geol. Soc. Am. Abstr. Program 38:85. 


\section{QUERIES TO THE AUTHOR}

1 I inserted a temporary running head. Please revise or replace as necessary.

2 Here and throughout, you preface many of the age ranges with "ca." A hyphen is necessary after ca. when these ranges are used as adjectives, which I think makes the phrases somewhat cumbersome. To prevent that problem, I replaced "ca." with a tilde where appropriate (e.g., 980-1080 Ma) throughout the article. Changes okay?

3 Re the figure 3 legend, Williams et al. 1995 does not have a corresponding entry in Refs Cited. Please provide info or mark this citation for deletion. Also, correct to change Becker et al. 2004 to 2005 as shown?

4 In the sentence that begins "In West Virginia," the relationships of the terms shown are not clear to me. Is a word missing after Chattanooga (i.e., the Chattanooga [something])? Would it be correct to say "...represented by the Brallier, Chemung, Foreknobs, Hampshire, and Pocono formations in the Devonian-Lower Mississippian Chattanooga )"?

5 Correct here to change Fedo et al. 2004 to 2003 as shown?

6 Lukert and Bank 1984 does not appear in References Cited. Please provide reference info or mark this citation for deletion.

7 In the sentence that begins "Synorogenic igneous," the phrase "contributed an important source" seemed awkward to me. Okay to change as shown?

8 Hoffman 1991 does not appear in References Cited. Please provide reference info or mark this citation for deletion.

9 Table A1 cites Englund 1979, but there is no corresponding entry in Refs Cited. Please provide reference information or mark this citation for deletion. There is an identical problem with Folk 1960.
10 In "Laser spot selection," are you saying the zircon cores are favored by the targeted areas or by the laser spot? Also, I don't understand what you mean by "favored." Do you mean zircon cores are more likely to be found in targeted areas that are sufficiently clean and large?

11 Re the zircon standard here, please tell me what SL stands for.

12 Stacey and Kramers 1975 does not appear in References Cited. Please provide reference info or mark this citation for deletion.

13 Re table 1, Robert et al. 1992 does not appear in Refs Cited. Please provide reference info or mark this citation for deletion.

14 The first clause of "Minor age populations" was not clear to me. Okay to change sentence as shown?

$15 \operatorname{Re} \mathrm{N}=2$, what does the capital italic $\mathrm{N}$ represent? (I assume $\mathrm{n}=185$ is the sample size.)

16 Tollo et al. 2004 does not have its own entry in Ref Cited. Instead, it appears as the "parent" source in the reference entries for Bream et al. 2004 and Hatcher et al. 2004. Do you want to provide complete reference info for Tollo et al. so it can be listed in Ref Cited, or should the Tollo et al. 2004 citation here be changed to Bream et al. 2004 and/ or Hatcher et al. 2004?

17 Bradley and Hanson 1989 does not appear in Refs Cited. Please provide reference info or mark this citation for deletion.

18 In "Together these," the phrase "before the conventional wisdom" was grammatically incomplete. Okay to revise as shown?

19 In "The different age," the phrase "is likely attributed" didn't seem quite right. Okay to change as shown, or should it say "is probably attributable to"? 
23 Re Cardwell et al., please provide scale and name and location for the map's publisher.

24 Davis and Ehrlich 1974 is not cited in the text. Please provide a citation or mark this reference for deletion.

25 Hammer 1998 is not cited in the text. Please provide a citation or mark this reference for deletion.
26 Secor et al. 1983 is not cited in the text. Please provide a citation or mark this reference for deletion.

27 Thomas et al. 2009 is not cited in the text. Please provide a citation or mark this reference for deletion. 


\section{The Journal of Geology}

The University of Chicago Press

1427 E. $60^{\text {th }}$ St.

Chicago, IL 60637

FAX (773) 753-3616

\section{PAGE CHARGE FORM}

$x$ To encourage the widest distribution of the Journal by keeping subscription costs low, we charge $\$ \mathbf{7 5 . 0 0}$ per Journal page.

$x \quad$ Papers in excess of 22 printed pages are assessed an additional $\$ \mathbf{3 0 . 0 0}$ per excess page.

$X \quad$ For those authors whose articles include color figures in their print versions, we charge $\mathbf{\$ 1 5 0 . 0 0}$ per color Journal page. Please note that this color fee is non-negotiable.

$x$ Send forms and billing questions to Cindy Garrett, Billing Manager:

○ (773) 753-8028, fax (773) 753-3616, cgarrett@press.uchicago.edu.

$x$ MAKE CHECKS AND PURCHASE ORDERS PAYABLE TO: The University of Chicago Press.

$X$ Purchase orders will not be processed without a number. Please list vendor as:

- The University of Chicago Press, 11030 Langley Avenue, Chicago, Illinois 60623.

$\mathrm{X}$ If the purchase order is sent separately from this form, it must be marked "confirming" and mailed to:

○ Cindy Garrett, Journals Division, The University of Chicago Press, 1427 E. 60th Street, Chicago, Illinois, 60637.

$x$ All purchase orders must include the following information:

$\circ \quad$ The name of the journal; the issue date (month and year); the author's name; and the amount of the invoice.

Please indicate your article information and your preferred payment method below. An invoice will be sent to you upon publication of your article.

\section{ARTICLE INFORMATION}

Volume Issue Month Year

Manuscript No. Total Pages

Title

\section{BILLING INFORMATION}

( ) I can pay page charges for my article.

( ) I request a partial waiver from page charges and can contribute $\$$ $\$ 300.00$, U.S. funds only.) for my article. (Min. contribution is

( ) I request a full waiver from page charges. Please state reason below:

Send invoices to:

\section{PAYMENT INFORMATION}

1. Institutional Purchase Order No.

Purchase Order: attached ( ) to come ( )

2. Check or Money Order: ( )

3. Credit card: () Visa ( ) MasterCard

Member name as it appears on card:

Card No.

Exp. Date

Signature

Phone No.

E-mail

Special Billing Instructions: 